archives-ouvertes

\title{
Biotic and abiotic degradation of the sea ice diatom biomarker IP25 and selected algal sterols in near-surface Arctic sediments \\ Jean-Francois Rontani, Simon Belt, Remi Amiraux
}

\section{To cite this version:}

Jean-Francois Rontani, Simon Belt, Remi Amiraux. Biotic and abiotic degradation of the sea ice diatom biomarker IP25 and selected algal sterols in near-surface Arctic sediments. Organic Geochemistry, Elsevier, 2018, 118, pp.73-88. <10.1016/j.orggeochem.2018.01.003>. <hal-02024258>

\section{HAL Id: hal-02024258 \\ https://hal-amu.archives-ouvertes.fr/hal-02024258}

Submitted on 25 Feb 2019

HAL is a multi-disciplinary open access archive for the deposit and dissemination of scientific research documents, whether they are published or not. The documents may come from teaching and research institutions in France or abroad, or from public or private research centers.
L'archive ouverte pluridisciplinaire HAL, est destinée au dépôt et à la diffusion de documents scientifiques de niveau recherche, publiés ou non, émanant des établissements d'enseignement et de recherche français ou étrangers, des laboratoires publics ou privés. 


\title{
Biotic and abiotic degradation of the sea ice diatom biomarker $\mathrm{IP}_{25}$ and selected algal sterols in near-surface Arctic sediments
}

\author{
Jean-François Rontani ${ }^{\mathrm{a}, *}$, Simon T. Belt ${ }^{\mathrm{b}}$, Rémi Amiraux ${ }^{\mathrm{a}}$ \\ a Aix Marseille University, Université de Toulon, CNRS/INSU/IRD, Mediterranean Institute of Oceanography (MIO) UM 110, 13288 Marseille, France \\ ${ }^{\mathrm{b}}$ Biogeochemistry Research Centre, School of Geography, Earth and Environmental Sciences, University of Plymouth, Drake Circus, Plymouth, Devon PL4 8AA, UK
}

Keywords:

$\mathrm{IP}_{25}$

Sterols

Arctic sediments

Degradation

Autoxidation

Aerobic and anaerobic biodegradation

Palaeo sea ice reconstruction

\begin{abstract}
A B S T R A C T
The organic geochemical $\mathrm{IP}_{25}$ (Ice Proxy with 25 carbon atoms) has been used as a proxy for Arctic sea ice in recent years. To date, however, the role of degradation of $\mathrm{IP}_{25}$ in Arctic marine sediments and the impact that this may have on palaeo sea ice reconstruction based on this biomarker have not been investigated in any detail. Here, we show that $\mathrm{IP}_{25}$ may be susceptible to autoxidation in near-surface oxic sediments. To arrive at these conclusions, we first subjected a purified sample of $\mathrm{IP}_{25}$ to autoxidation in the laboratory and characterised the oxidation products using high resolution gas chromatography-mass spectrometric methods. Most of these $\mathrm{IP}_{25}$ oxidation products were also detected in near-surface sediments collected from Barrow Strait in the Canadian Arctic, although their proposed secondary oxidation and the relatively lower abundances of $\mathrm{IP}_{25}$ in other sediments probably explain why we were not able to detect them in material from other parts of the region. A rapid decrease in $\mathrm{IP}_{25}$ concentration in some near-surface Arctic marine sediments, including examples presented here, may potentially be attributed to at least partial degradation, especially for sediment cores containing relatively thick oxic layers representing decades or centuries of deposition. An increase in the ratio of two common phytoplanktonic sterols - epi-brassicasterol and 24-methylenecholesterol - provides further evidence for such autoxidation reactions given the known enhanced reactivity of the latter to such processes reported previously. In addition, we provide some evidence that biodegradation processes also act on $\mathrm{IP}_{25}$ in Arctic sediments. The oxidation products identified in the present study will need to be quantified more precisely in downcore records in the future before the effects of degradation processes on $\mathrm{IP}_{25}$-based palaeo sea ice reconstruction can be fully understood. In the meantime, a brief overview of some previous investigations of $\mathrm{IP}_{25}$ in relatively shallow Arctic marine sediments suggests that overlying climate conditions were likely dominant over degradation processes, as evidenced from often increasing $\mathrm{IP}_{25}$ concentration downcore, together with positive relationships to known sea ice conditions.
\end{abstract}

\section{Introduction}

Over the past decade, the Arctic sea ice diatom biomarker $\mathrm{IP}_{25}$ (Ice Proxy with 25 carbons atoms; Belt et al., 2007) has emerged as a useful proxy for the past occurrence of seasonal (spring) sea ice when detected in Arctic marine sediments (for a review see Belt and Müller, 2013). Consistent with its origin (i.e., sea iceassociated or sympagic diatoms; Brown et al., 2014), $\mathrm{IP}_{25}$ is a common component of surface sediments across the Arctic (Müller et al., 2011; Stoynova et al., 2013; Xiao et al., 2013, 2015; Navarro-Rodriguez et al., 2013; Ribeiro et al., 2017; Köseoğlu et al., 2018), while its variability in downcore abundance is generally believed to reflect temporal changes to spring sea ice cover,

\footnotetext{
* Corresponding author.

E-mail address: jean-francois.rontani@mio.osupytheas.fr (J.-F. Rontani).
}

especially when its concentration profile is considered alongside those of other biomarkers indicative of open-water or ice-edge conditions (e.g., Müller et al., 2009, 2011; Belt et al., 2015), through a combined $\mathrm{IP}_{25}$-phytoplankton biomarker index ( $\mathrm{PIP}_{25}$ ) (Müller et al., 2011), or a multivariate biomarker approach (Köseoğlu et al., 2018). To date, however, the majority of $\mathrm{IP}_{25}$-based studies have focused either on surface sediment analysis or on long-term (multi-centennial or longer) records. Thus, surface sediment analyses have addressed aspects of proxy calibration, generally by comparison of $\mathrm{IP}_{25}$ and other biomarker content with satellitebased measurements of sea ice conditions (Müller et al., 2011; Navarro-Rodriguez et al., 2013; Stoynova et al., 2013; Xiao et al., 2013, 2015), while temporal studies have concentrated mainly on the reconstruction of sea ice conditions on a multi-centennial scale during the Holocene (e.g., Vare et al., 2009; Belt et al., 2010; Müller et al., 2012; Berben et al., 2014, 2017; Hörner et al., 
2016, 2017; Stein et al., 2017), recent glacial/interglacial intervals (Müller and Stein, 2014; Hoff et al., 2016), the Mid-Pleistocene Transition (Detlef et al., 2018), and even longer timeframes extending back to the Pliocene/Pleistocene boundary and the late Miocene (Stein and Fahl, 2013; Knies et al., 2014; Stein et al., 2016). One key attribute of $\mathrm{IP}_{25}$ as a sea ice proxy is its apparent relative stability in sediments. Indeed, the identification of $\mathrm{IP}_{25}$ in sediments several million years old (Knies et al., 2014; Stein et al., 2016) has been attributed, in part, to such stability, and is supported by laboratory-based investigations, where it has been shown to be significantly less reactive towards degradation process such as photo-oxidation and autoxidation, at least compared to other common phytoplanktonic lipids (Rontani et al., 2011, 2014). As such, sedimentary signals have been interpreted as reflecting climatic (sea ice) conditions rather than diagenetic artefacts, although the possibility of some diagenetic over-printing of the environmental signal has been noted (e.g., Belt and Müller, 2013; Polyak et al., 2016). In contrast, temporal investigations covering recent decades or centuries are less common, although some studies from North Iceland (Massé et al., 2008; Andrews et al., 2009), East Greenland (Alonso-García et al., 2013; Kölling et al., 2017), the Barents Sea (Vare et al., 2010; Köseoğlu et al., 2018), northern Baffin Bay (Cormier et al., 2016) and the ChukchiAlaskan margin (Polyak et al., 2016) have been reported. Such studies are somewhat different from those carried out on surface sediments (typically $0-1 \mathrm{~cm}$ ) or longer timeframe investigations generally conducted on material from gravity/piston cores since, in some cases, at least, they likely result from analysis of material that spans the oxic/anoxic (redox) sediment boundary. However, such boundary layers are not generally identified (reported), even though they are likely found in the upper few centimetres of box cores or multi-cores, which reflect accumulation over decades or recent centuries for many Arctic Shelf regions (e.g., Stein and Fahl, 2000; Darby et al., 2006; Mudie et al., 2006; Maiti et al., 2010; Vare et al., 2010). On the other hand, in the central Arctic Ocean, such a layer may reflect substantially longer-term accumulation due to much lower sedimentation rates (e.g., Stein et al., 1994a,b).

The rate and extent of degradation of sedimentary organic compounds is strongly dependent on the molecular structure of the substrate, protective effects offered by association of organic matter with particle matrices, and the length of time accumulating particles are exposed to molecular oxygen in sedimentary pore waters (Henrich, 1991; Hartnett et al., 1998). The main degradative processes in the oxic layer of sediments are aerobic biodegradation and autoxidation. Numerous organisms, including bacteria, fungi and micro- and macrofauna, are responsible for the aerobic biodegradation of organic carbon in sediments (Fenchel et al., 1998) and almost all of these organisms have the enzymatic capacity to perform a total mineralization of numerous organic substrates (Kristensen, 2000). Although autoxidation of organic matter involving spontaneous free radical reaction of organic compounds with $\mathrm{O}_{2}$ has been rather under-considered in the marine realm, it is now known that autoxidative processes can act very intensively on vascular plant debris in Arctic sediments (Rontani et al., 2017). This high autoxidation efficiency likely reflects the enhanced photooxidation of senescent vascular plants in the region (thus yielding high amounts of hydroperoxides), together with high lipoxygenase activity (a potential source of radicals; Fuchs and Spiteller, 2014). Indeed, the latter mechanism has recently been observed in sinking particles dominated by ice algae (Amiraux et al., 2017) and in particles discharged from the Mackenzie River (Galeron et al., 2018).

The principal aim of the current study, therefore, was to investigate whether we could provide evidence for oxidative degradation processes acting on $\mathrm{IP}_{25}$ in near-surface Arctic sediments and thus, potentially, on any resultant palaeo sea ice reconstructions. To achieve this, we first carried out laboratory-based oxidation of purified $\mathrm{IP}_{25}$ and carried out product identification using high resolution mass spectral analysis. Since $\mathrm{IP}_{25}$ was shown previously to be relatively resistant to oxidation (Rontani et al., 2014), more powerful oxidizing conditions were used. We then investigated the occurrence of the same oxidation products in sediment samples taken from box cores retrieved from three regions of the Canadian Arctic. To complement the $\mathrm{IP}_{25}$-based findings, we also measured the ratios of two common algal sterols epi-brassicasterol and 24-methylenecholesterol - to provide further evidence of different oxidative pathways under oxic and anoxic conditions. Geochemical analysis of the box cores revealed variable redox boundary depths, which provided further context for interpreting the biomarker data.

\section{Experimental}

\subsection{Sediment and sea ice algal sampling}

Investigations of in situ degradation processes were performed on sediment material and sea ice algal aggregates. Sediment material was obtained from three locations within the Canadian Arctic Archipelago (CAA) on board the CCGS Amundsen in 2005 and 2007 (Vare et al., 2009; Belt et al., 2010, 2013). Sampling locations correspond to Barrow Strait (STN 4), Viscount Melville Sound (STN 308) and the western Amundsen Gulf (STN 408) (Fig. 1). In each case, box cores were collected, sectioned on board, with subsamples ( $1 \mathrm{~cm}$ resolution) then being freeze-dried before storage between $-20{ }^{\circ} \mathrm{C}$ and $+4{ }^{\circ} \mathrm{C}$ prior to analysis. Regular monitoring of $\mathrm{IP}_{25}$ concentration in these sediments stored under such conditions (since their collection) has not revealed any significant degradation (i.e. < 10\%; Cabedo-Sanz et al., 2016). Previous reports of sedimentation rates from the study area (e.g., $0.15 \mathrm{~cm} / \mathrm{yr}$ for the Barrow Strait (STN 4) core (Belt et al., 2010)) and preliminary additional ${ }^{210} \mathrm{~Pb}$ data (S. Schmidt, personal communication) suggest that box cores (ca. $20 \mathrm{~cm}$ ) from the region typically represent decades to centuries of accumulation. A sample of floating sea ice algal aggregates was obtained from Resolute Passage (western Barrow Strait) in 2012 as described by Brown et al. (2014).

Redox boundary layers in each of the box cores were identified using the change (reduction) in Mn content as described previously (Vare et al., 2009; Brown, 2011 and References cited therein). Using this approach, redox boundaries were identified at ca. $2 \mathrm{~cm}$ in the box core from Barrow Strait (STN 4) and at ca. $11 \mathrm{~cm}$ and ca. $8 \mathrm{~cm}$ in box cores from Viscount Melville Sound (STN 308) and the western Amundsen Gulf (STN 408), respectively (L. Vare, personal communication).

\section{2. $I P_{25}$ isolation}

A sample of $\mathrm{IP}_{25}$ (ca. 99\%) was obtained by extraction of a multi$\mathrm{kg}$ quantity of sediment from Barrow Strait in the Canadian Arctic (STN 4; Fig. 1) and purification by a combination of open column chromatography $\left(\mathrm{SiO}_{2}\right.$; hexane) and $\mathrm{Ag}^{+} \mathrm{HPLC}$ as described previously in detail by Belt et al. (2012).

\subsection{Production of $I P_{25}$ oxidation products}

All procedures were carried out on a ca. $10-50 \mu \mathrm{g}$ scale. Oxidation of $\mathrm{IP}_{25}$ using $\mathrm{RuCl}_{3}$ and tert-butyl hydroperoxide in cyclohexane at room temperature for $16 \mathrm{~h}$ (Seki et al., 2008) produced 3,9,13-trimethyl-6-(1,5-dimethylhexyl)-tetradec-1-en3-ol (1) and 3,9,13-trimethyl-6-(1,5-dimethylhexyl)-tetradec-2en-1-ol (2) with yields of $5 \%$ and $2 \%$, respectively. 


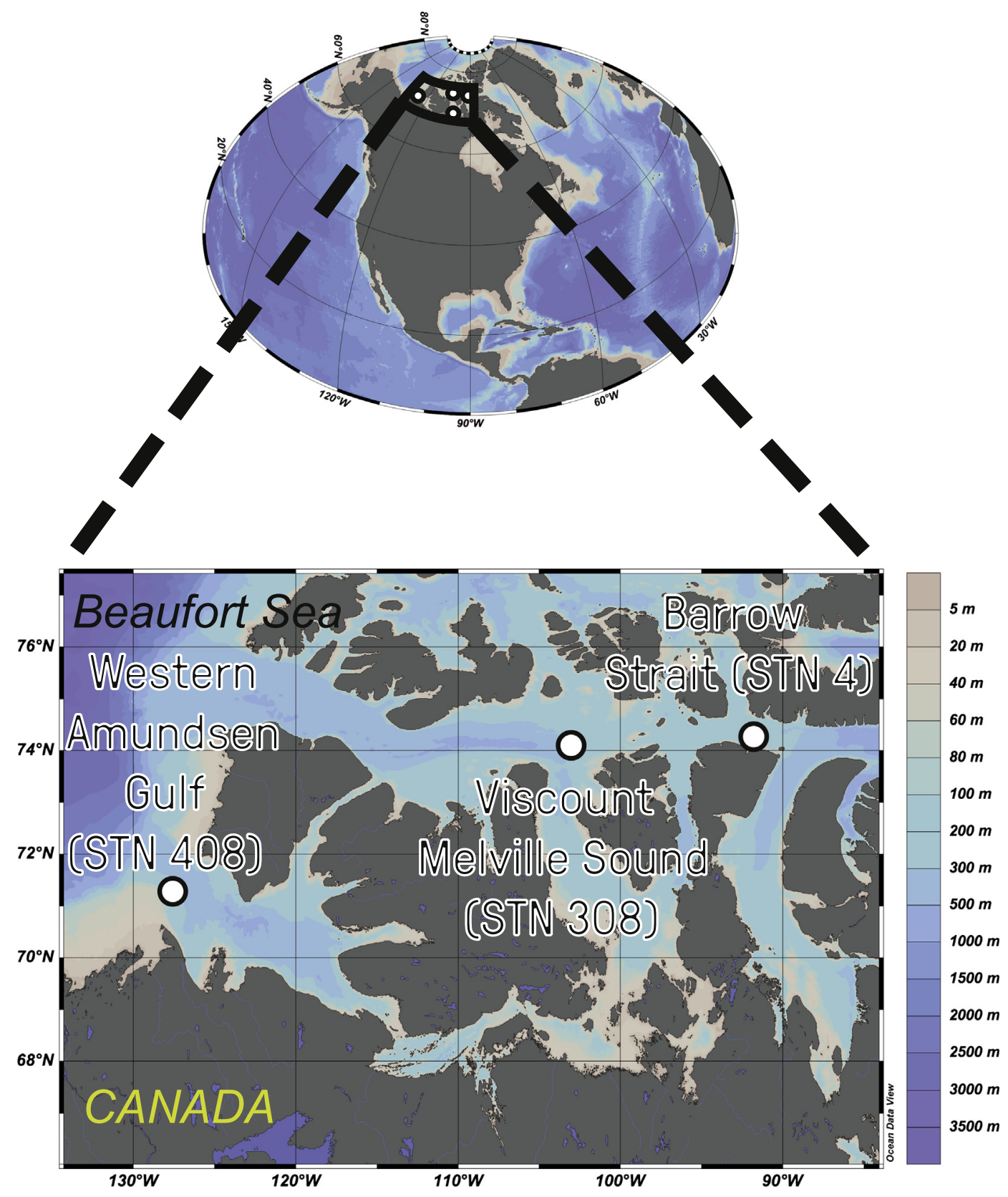

Fig. 1. Map showing the sampling locations.

$\mathrm{OsO}_{4}$ oxidation of $\mathrm{IP}_{25}$ in anhydrous dioxane/pyridine (McCloskey and McClelland, 1965) afforded 3,9,13-trimethyl-6(1,5-dimethylhexyl)-tetradecan-1,2-diol (6) as the major product (ca. 45\%) together with smaller amounts of 2,8,12-trimethyl-5(1,5-dimethylhexyl)-tridecanoic acid (7) (ca. 6\%) resulting from diol cleavage and subsequent oxidation of the aldehyde thus formed.

The structures of all $\mathrm{IP}_{25}$ oxidation products are shown in Appendix A. Due to the very low amounts of $\mathrm{IP}_{25}$ available, compounds 1, 2, 6 and 7 could not be produced in sufficient amounts to permit quantification, although comparison of their mass spectra and retention times with compounds detected in sediments confirmed their identification.

\subsection{Induction of autoxidation in solvent}

Autoxidation experiments were performed under an atmosphere of air in $15 \mathrm{ml}$ screw-cap flasks containing $\operatorname{IP}_{25}(10 \mu \mathrm{g})$, tert-butyl hydroperoxide ( $200 \mu \mathrm{l}$ of a $6.0 \mathrm{M}$ solution in decane), di-tert-butyl nitroxide $(1.2 \mathrm{mg})$ and hexane $(2 \mathrm{ml})$. After stirring, the flask was incubated in the dark at $65{ }^{\circ} \mathrm{C}$. A relatively high temperature was selected in order to accelerate the autoxidation reactions. Aliquots $(200 \mu \mathrm{l})$ were withdrawn from the reaction mixture after incubation for different times. Each sub-sample was evaporated to dryness under a stream of nitrogen and analyzed by gas chromatography-electron ionization quadrupole time of flight mass spectrometry (GC-QTOFMS) after $\mathrm{NaBH}_{4}$ reduction (see Section 2.5) and derivatization (see Section 2.8) for identification of hydroxylated oxidation products.

\subsection{Reduction of oxidation products}

Hydroperoxides resulting from $\mathrm{IP}_{25}$ oxidation were reduced to the corresponding alcohols by reaction with excess $\mathrm{NaBH}_{4}$ in diethyl ether:methanol ( $4: 1, \mathrm{v}: \mathrm{v}, 10 \mathrm{mg} / \mathrm{mg}$ of residue) at room temperature (1h). After reduction, a saturated solution of $\mathrm{NH}_{4} \mathrm{Cl}$ 
(10 mL) was added cautiously to remove any unreacted $\mathrm{NaBH}_{4}$. The $\mathrm{pH}$ was then adjusted to 1 with dilute $\mathrm{HCl}(2 \mathrm{~N})$ and the mixture shaken and extracted with hexane:chloroform (5 ml, 4:1, v:v; $\times 3$ ). The combined extracts were dried over anhydrous $\mathrm{Na}_{2} \mathrm{SO}_{4}$, filtered and evaporated to dryness under a stream of nitrogen.

\subsection{Aerobic biodegradation of phytoplankton sterols}

Aerobic biodegradation of phytoplankton cells was performed using the upper layer $(0-1 \mathrm{~cm})$ of Arctic sediments collected in July 2016 from Davis Strait $\left(70^{\circ} 29^{\prime} 55.56^{\prime \prime} \mathrm{N}, 59^{\circ} 31^{\prime} 30.24^{\prime \prime} \mathrm{W}\right)$ during the GreenEdge cruise on board the CCGS Amundsen as bacterial inoculum. Enrichment cultures were incubated in the dark in $250 \mathrm{ml}$ Erlenmeyer flasks containing $50 \mathrm{ml}$ portions of an enrichment medium consisting of LB medium $(20 \mathrm{ml})$ and phytoplankton suspension $(10 \mathrm{ml})$ (10 $\mathrm{mg}$ dry weight) as carbon source. Samples were maintained at $2{ }^{\circ} \mathrm{C}$ (a temperature close to that of Arctic waters) and agitated using a reciprocal shaker for different times. The amounts of 24-methylenecholesterol and epi-brassicasterol in the sediment inoculum were negligible relative to those in the phytoplankton suspension. These phytoplankton cells (mainly composed of diatoms) were collected in Commonwealth Bay (East Antarctica, $66^{\circ} 56^{\prime} S ; 1^{\circ} 2^{\circ} 27^{\prime} \mathrm{E}$ ) during the IPEV-COCA2012 cruise in January 2012 as described previously (Rontani et al., 2014). After incubation, phytoplankton material was recovered by filtration on GF/F filters and saponified as described in Section 2.7.

\subsection{Sediment and sea ice algal treatment}

Sediments from box cores (i.e., STN 4, 308, 408) or sea ice algae (19.3 mg dry weight) were placed in $\mathrm{MeOH}(15 \mathrm{ml})$ and hydroperoxides were reduced to the corresponding alcohols with excess $\mathrm{NaBH}_{4}\left(70 \mathrm{mg}, 30 \mathrm{~min}\right.$ at $\left.20^{\circ} \mathrm{C}\right)$. Following the reduction step, water $(15 \mathrm{ml})$ and $\mathrm{KOH}(1.7 \mathrm{~g})$ were added and the mixture saponified by refluxing $(2 \mathrm{~h})$. After cooling, the contents of the flask were acidified with $\mathrm{HCl}$ to $\mathrm{pH} 1$ and extracted three times with dichloromethane (DCM) $(30 \mathrm{ml})$. The combined DCM extracts were dried over anhydrous $\mathrm{Na}_{2} \mathrm{SO}_{4}$, filtered and concentrated to give a total lipid extract (TLE). Since $\mathrm{IP}_{25}$ oxidation product content was quite low relative to other lipids, accurate quantification required further separation of the TLE using column chromatography (silica; Kieselgel $60,8 \mathrm{~cm} \times 0.5 \mathrm{~cm}$ i.d.). $\mathrm{IP}_{25}$ was obtained by elution with hexane $(10 \mathrm{ml})$ and its oxidation products by subsequent elution with DCM $(10 \mathrm{ml})$. Additional elution with $\mathrm{MeOH}(10 \mathrm{ml})$ was carried out to recover the more polar lipid compounds. Relative $\mathrm{IP}_{25}$ content was determined using the method of Vare et al. (2009) and Belt et al. (2010) and some uncalibrated data (STN 308) were presented previously by Brown (2011). Here, all previous GC-MS data were re-analyzed and converted to absolute concentrations using instrumental response factors derived from solutions of known $\mathrm{IP}_{25}$ concentration (Belt et al., 2012). Biomarker data were further normalised to total organic carbon (TOC) to accommodate possible changes in burial efficiency. TOC data were obtained following removal of inorganic carbonate from sediment material according to the method of Berben et al. (2017).

\subsection{Derivatization of hydroxyl-containing products}

In order to analyze for hydroxylated products (i.e. alcohols and carboxylic acids), DCM- and $\mathrm{MeOH}-$ eluted fractions were derivatized by dissolving them in $300 \mu \mathrm{l}$ pyridine/bis-(trimethylsilyl)tri fluoroacetamide (BSTFA; Supelco; $2: 1, \mathrm{v}: \mathrm{v})$ and silylated $\left(50{ }^{\circ} \mathrm{C}, 1\right.$ h). After evaporation to dryness under a stream of $\mathrm{N}_{2}$, the derivatized residue was re-dissolved in $100 \mu \mathrm{l}$ BSTFA (to avoid desilylation of fatty acids), together with an amount of co-solvent (ethyl acetate) dependent on the mass of the TLE, and then analyzed using GC-QTOFMS.

\subsection{GC-QTOFMS analyses}

Accurate mass spectra were obtained with an Agilent 7890B/7200 GC-QTOFMS System (Agilent Technologies, Parc Technopolis - ZA Courtaboeuf, Les Ulis, France). A cross-linked 5\% phenyl-methylpolysiloxane (Macherey Nagel; Optima 5-MS Accent) column ( $30 \mathrm{~m} \times 0.25 \mathrm{~mm}, 0.25 \mu \mathrm{m}$ film thickness) was employed. Analysis was performed with an injector operating in pulsed splitless mode at $280^{\circ} \mathrm{C}$ and the oven temperature programmed from $70^{\circ} \mathrm{C}$ to $130^{\circ} \mathrm{C}$ at $20^{\circ} \mathrm{C} / \mathrm{min}$, then to $250^{\circ} \mathrm{C}$ at $5{ }^{\circ} \mathrm{C} / \mathrm{min}$ and then to $300{ }^{\circ} \mathrm{C}$ at $3{ }^{\circ} \mathrm{C} / \mathrm{min}$. The carrier gas (He) was maintained at $0.69 \times 10^{5} \mathrm{~Pa}$ until the end of the temperature program. Instrument temperatures were $300{ }^{\circ} \mathrm{C}$ for transfer line and $230{ }^{\circ} \mathrm{C}$ for the ion source. Accurate mass spectra were recorded across the range $m / z 50-700$ at $4 \mathrm{GHz}$ with nitrogen as collision gas $(1.5 \mathrm{ml} / \mathrm{min})$. The QTOFMS instrument provided a typical resolution ranging from 8009 to 12,252 from $\mathrm{m} / z 68.9955$ to 501.9706 . Perfluorotributylamine (PFTBA) was utilized for daily MS calibration. Structural assignments were based on interpretation of accurate mass spectral fragmentations and confirmed by comparison of retention times and mass spectra of oxidation products with those of authentic compounds, when available.

\section{Results}

3.1. Autoxidation and biodegradation rates of epi-brassicasterol, 24methylenecholesterol and $I P_{25}$

Autoxidation rates of $24 \alpha$-methylcholesta-5,22E-dien-3 $\beta$-ol (epi-brassicasterol) and 24-methylcholesta-5,24(28)-dien-3 $\beta$-ol (24-methylenecholesterol) were previously measured in phytoplankton cells (Rontani et al., 2014). In order to compare biodegradation rates of these two sterols, phytoplanktonic cells were incubated in the presence of sediment inoculum under oxic conditions. We observed a strong depletion of both sterols (close to $90 \%$ after incubation for 1 month at $2{ }^{\circ} \mathrm{C}$ ), although their biodegradation rates were quite similar (Table 1 ). The pseudo-first order rate constant $(\mathrm{k})$ for the biodegradation of each sterol was obtained from the gradient of the regression lines determined according to

Table 1

Pseudo first order degradation rate constants of epi-brassicasterol and 24-methylenecholesterol during in vitro incubations and in Arctic oxic sediments.

\begin{tabular}{|c|c|c|c|c|c|c|}
\hline & $\mathrm{k}_{\text {Bra }}\left(\mathrm{h}^{-1}\right)^{\mathrm{a}}$ & $r^{2}$ & $\mathrm{n}$ & $\mathrm{k}_{24-\mathrm{Me}}\left(\mathrm{h}^{-1}\right)^{\mathrm{b}}$ & $r^{2}$ & $\mathrm{n}$ \\
\hline Autoxidation in algal cells (seawater $\left.+\mathrm{Fe}^{2+}\right)^{\mathrm{C}}$ & $2.9 \times 10^{-4}$ & 0.80 & 4 & $1.1 \times 10^{-3}$ & 0.85 & 4 \\
\hline Aerobic biodegradation of algal cells & $3.5 \times 10^{-3}$ & 0.95 & 4 & $3.6 \times 10^{-3}$ & 0.93 & 4 \\
\hline Degradation in sediments from station $308^{d}$ & $2.0 \times 10^{-6}$ & 0.86 & 6 & $3.3 \times 10^{-6}$ & 0.94 & 6 \\
\hline
\end{tabular}

\footnotetext{
a Pseudo first order degradation rate constant of epi-brassicasterol

b Pseudo first order degradation rate constant of 24-methylenecholesterol.

c Rontani et al. (2014).

d First $10 \mathrm{~cm}$.
} 

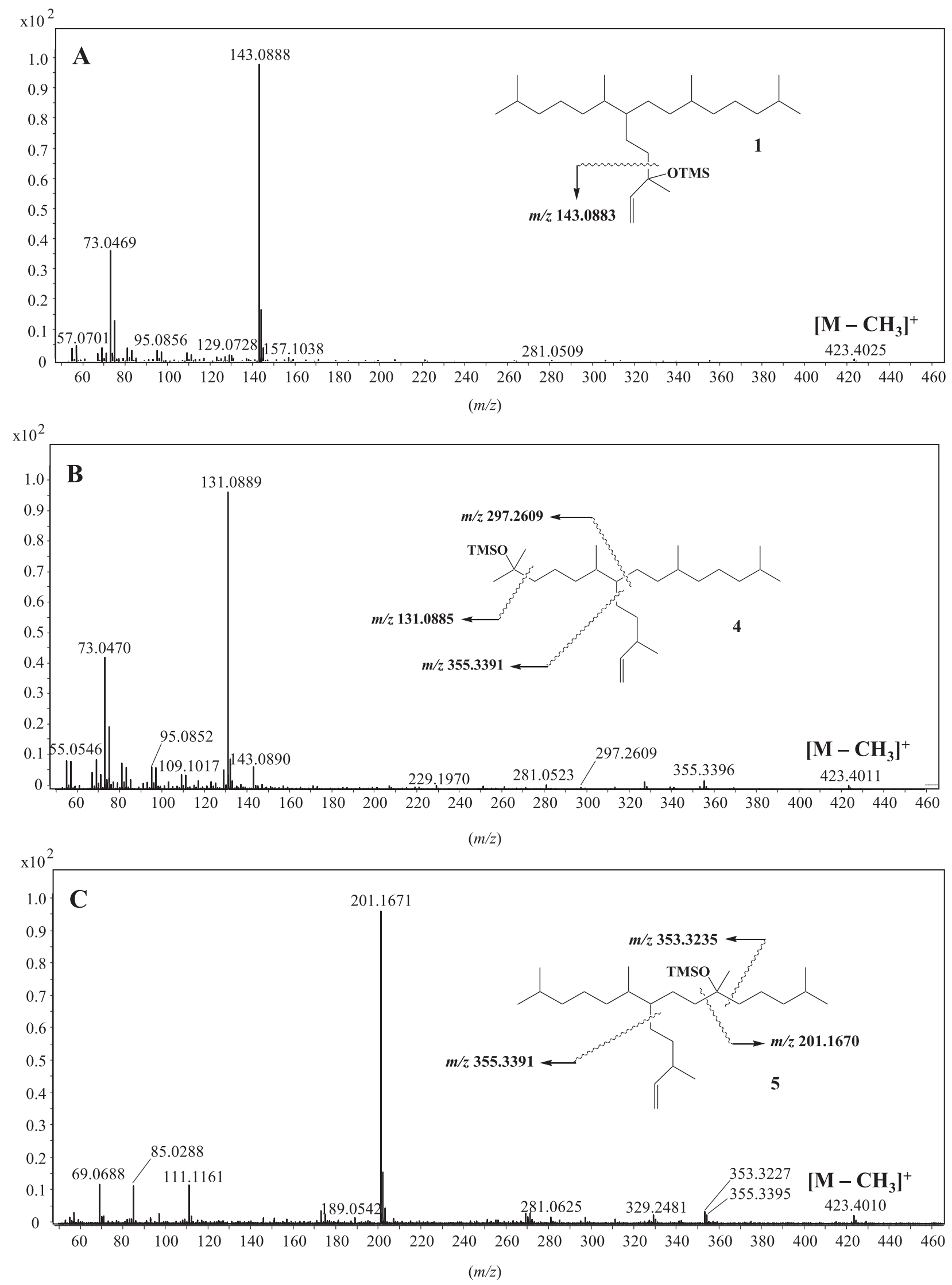

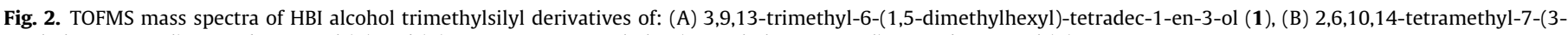
methylpent-4-enyl)-pentadecan-2-ol (4) and (C) 2,6,10,14-tetramethyl-9-(3-methylpent-4-enyl)-pentadecan-6-ol (5). 
the relationship $\ln \left(C / C_{0}\right)=-k t$, where $C$ is the concentration of an analyte at the time of sampling, $C_{o}$ is the initial concentration, and $\mathrm{t}$ corresponds to the duration of the incubation. For these experiments, a microbially mediated change in the sterol content is supported by the near invariance of the concentration of 24-ethylcholesta-3 $\beta, 5 \alpha, 6 \beta$-triol, a well-known autoxidation product of sitosterol (Rontani et al., 2009).

Incubation of hexane solutions of $\mathrm{IP}_{25}$ in the presence of tert-butyl hydroperoxide and di-tert-butyl nitroxide at $65{ }^{\circ} \mathrm{C}$, with subsequent $\mathrm{NaBH}_{4}$-reduction and silylation, yielded several HBI alcohol TMS derivatives (resulting from the reduction and the silylation of the corresponding, hydroperoxides, respectively) that could be identified by GC-QTOFMS. Specifically, the formation of 3,9,13-trimethyl-6-(1,5-dimethylhexyl)-tetradec-1-en-3-ol (1) and 3,9,13-trimethyl-6-(1,5-dimethylhexyl)-tetradec-2-en-1-ol (2) was supported by comparison of their accurate mass spectra (Fig. 2A) and retention times with those of reference compounds prepared by oxidation of purified $\mathrm{IP}_{25}$ (see Section 2.3). Furthermore, 2,6,10,14-tetramethyl-9-(3-methylpent-4-enyl)-pentadecan-2-ol (3), 2,6,10,14-tetramethyl-7-(3-methylpent-4-enyl)-pentadecan-2-ol (4) and 2,6,10,14-tetramethyl-9-(3-methylpent-4-enyl)-pentadecan-6-ol (5) could be tentatively identified on the basis of their a ccurate mass fragmentations (Fig. 2B and C).

\subsection{Degradation of $I P_{25}$, epi-brassicasterol and 24- methylenecholesterol in Arctic sediments}

$\mathrm{IP}_{25}$ concentrations (Supplementary Table S1) and the ratio epibrassicasterol/24-methylenecholesterol (Bra/24-Me) were monitored in the upper sections (up to ca. $20 \mathrm{~cm}$ ) of three short sediment cores collected from different regions of the Canadian Arctic, which possessed contrasting near-surface redox properties. Thus, sediments from Viscount Melville Sound (STN 308) and the western Amundsen Gulf (STN 408) exhibited a thick oxic layer $(11 \mathrm{~cm}$ and $8 \mathrm{~cm}$, respectively), while the redox boundary was much shallower (ca. $2 \mathrm{~cm}$ ) in the box core from Barrow Strait (STN 4). After an increase in the first $3 \mathrm{~cm}, \mathrm{IP}_{25}$ concentration (expressed relative to TOC) decreased substantially in the 3-11 cm sections of (oxic) sediments from Viscount Melville Sound (STN 308). Similarly, a reduction in $\mathrm{IP}_{25}$ concentration was identified in the top $3 \mathrm{~cm}$ of oxic sediments from the western Amundsen Gulf (STN 408) before a subsequent increase (ca. 3-11 cm) and then decrease (Fig. 3 ). In contrast, $\mathrm{IP}_{25}$ concentration remained relatively constant in the case of Barrow Strait (STN 4) sediments (Fig. 3). Concerning the two main sterols, the ratio Bra/24-Me remained relatively constant in anoxic sediments from Barrow Strait (STN 4), although it increased steadily in oxic sediments from Viscount Melville Sound (STN 308) (Fig. 3). Sediments from the western Amundsen Gulf (STN 408), Bra/24-Me increased strongly in the first $4 \mathrm{~cm}$, before decreasing and then stabilizing (Fig. 3).

Next, we aimed to identify $\mathrm{IP}_{25}$ autoxidation products in the DCM fractions of the TLEs of different sediments by comparison of accurate mass fragmentations and retention times with the oxidation products characterised during the thermal incubation reactions. Using this approach, we detected compounds 1, 3, 4 and 5 in sediments from Barrow Strait (STN 4), which also contained the highest concentrations of $\mathrm{IP}_{25}$ (Fig. 4). The combined relative abundance of these compounds (estimated on the basis of similar TOFMS responses to that of $\mathrm{IP}_{25}$ ) reached $8.8 \%$ of the amount of $\mathrm{IP}_{25}$ in the $1-2 \mathrm{~cm}$ layer and then decreased rapidly to $1.2 \%$ in the 3-4 cm horizon. In addition, 2,6,10,14-tetramethyl-7-(3-methylpenten-4-yl)-pentadecan-6-ol (8), which was absent in the incubation experiments, was also identified, albeit tentatively (Fig. 4B). In contrast, since the mass spectrum of the TMS derivative of the saturated tertiary $\mathrm{C}_{25} \mathrm{HBI}$ alcohol (C-7) had already been reported (Robson, 1987), we were able to investigate if the corresponding
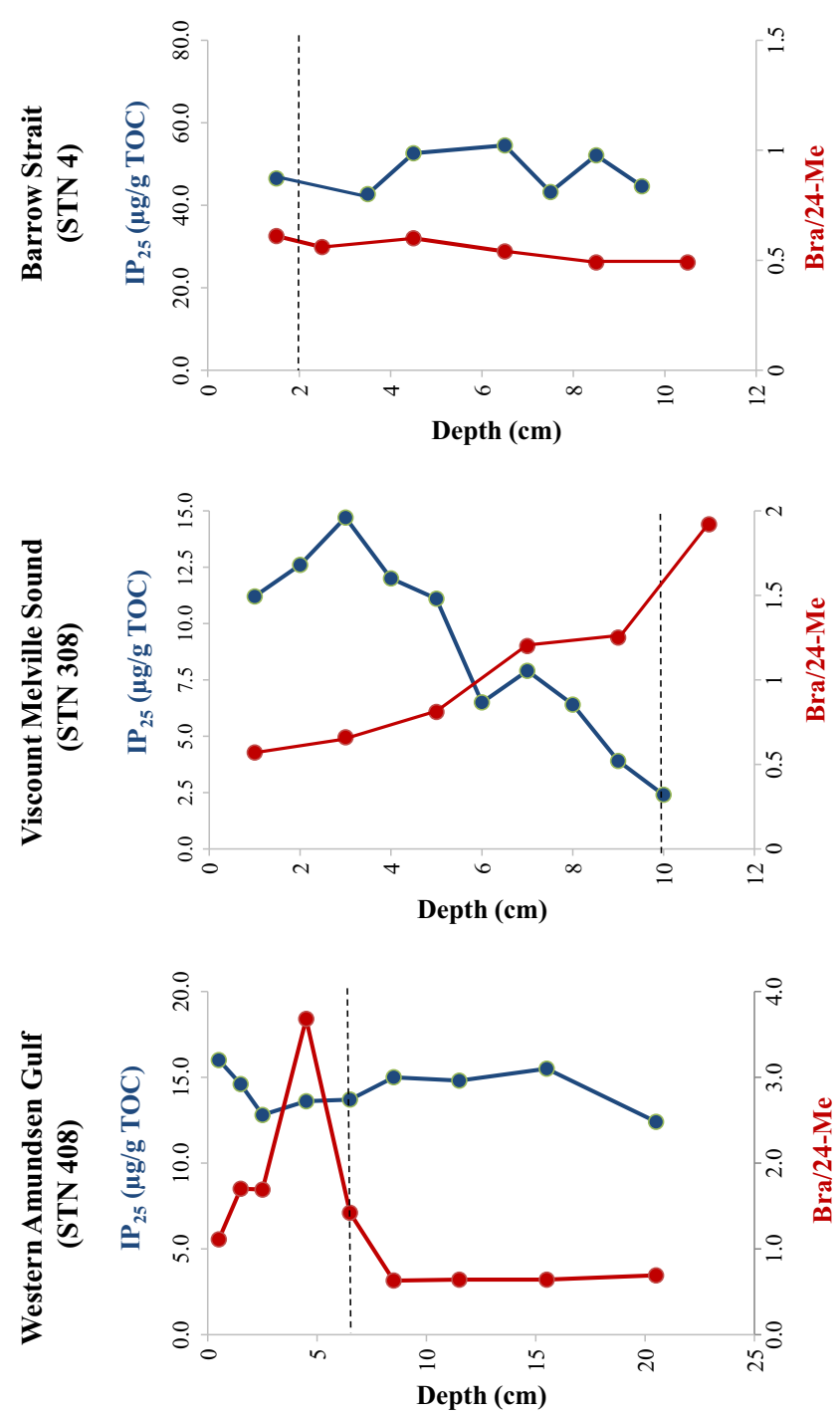

Fig. 3. Downcore plots of $\mathrm{IP}_{25}$ concentration and the epi-brassicasterol/24methylenecholesterol ( $\mathrm{Bra} / 24-\mathrm{Me}$ ) ratio for the three stations investigated. (The dashed lines represent the redox boundaries).

mono-unsaturated oxidation product was also present; however, no characteristic fragmentation ions corresponding to oxidation at C-7 of $\mathrm{IP}_{25}$ could be identified. Analysis of extracts by GC-QTOFMS did, however, enable us to detect 3,9,13-trimethyl-6-(1,5-dimethyl hexyl)-tetradecan-1,2-diol (6) in sediments from Barrow Strait (STN 4) and the western Amundsen Gulf (STN 408) (Fig. 5), while traces of 2,8,12-trimethyl-5-(1,5-dimethylhexyl)-tridecanoic acid (7) could be identified in Barrow Strait (STN 4) and Viscount Melville Sound (STN 308) sediments (Fig. 6). These two compounds were formally identified by comparison of their accurate mass spectra (Fig. 7) and retention times with those of standards. On the other hand, we failed to detect compounds 1-8 in floating sea ice algal aggregates from Resolute Passage despite the presence of relatively large amounts of $\mathrm{IP}_{25}$ within these samples (Brown et al., 2014).

\section{Discussion}

\subsection{Autoxidation of $I P_{25}$}

According to our product identifications, autoxidation of $\mathrm{IP}_{25}$ involves hydrogen atom abstraction by peroxyl radicals on the 


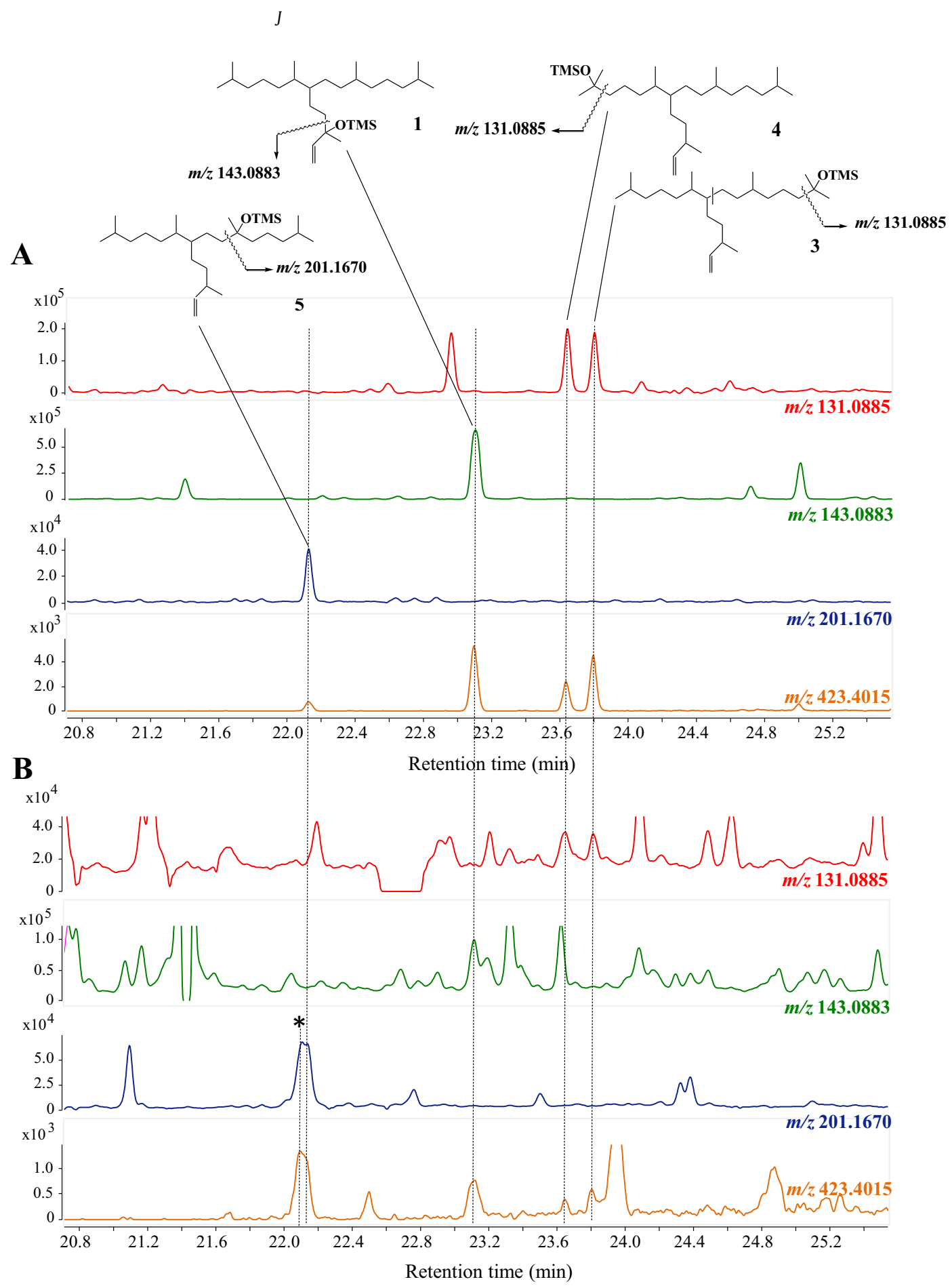

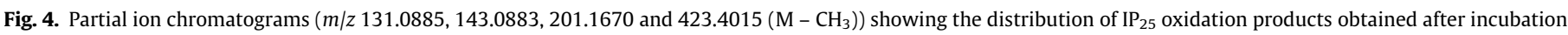

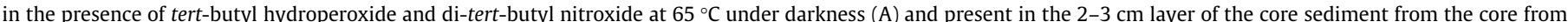

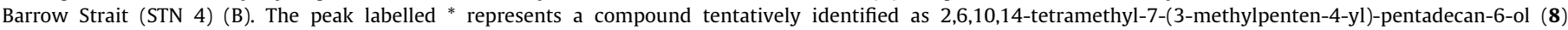
trimethylsilyl derivative.

allylic carbon C-22 and the tertiary carbon atoms C-2, C-10 and $\mathrm{C}-14$. Subsequent oxidation of the resulting radicals together with hydrogen abstraction from other substrate molecules leads to the formation of various hydroperoxides (Fig. 8). These labile compounds were reduced to their corresponding alcohols (1-5) during $\mathrm{NaBH}_{4}$-reduction and silylated prior to analysis by GC-QTOFMS. The failure to detect any autoxidation product resulting from reaction with either of the tertiary carbons C- 6 or C-7 is likely due to increased steric hindrance during hydrogen abstraction by the bulky tert-butylperoxyl radicals employed during the incubation.
Indeed, when comparing our data from laboratory and environmental samples, we note that the relative abundances of $\mathrm{IP}_{25}$ oxidation products are very different in Arctic sediments (Fig. 4B) compared to those from incubations in solvent (Fig. 4A), likely reflecting the contrasting nature of the peroxyl radicals involved during autoxidation. For example, the bulky tert-butylperoxyl radical pertinent to the laboratory-based incubations probably favours the attack of the less hindered external carbon atoms of $\mathrm{IP}_{25}$ (i.e. C-2 and C-14), while the unknown (structurally) peroxyl radicals acting in sediment seem to be less sensitive to such steric hindrance. 

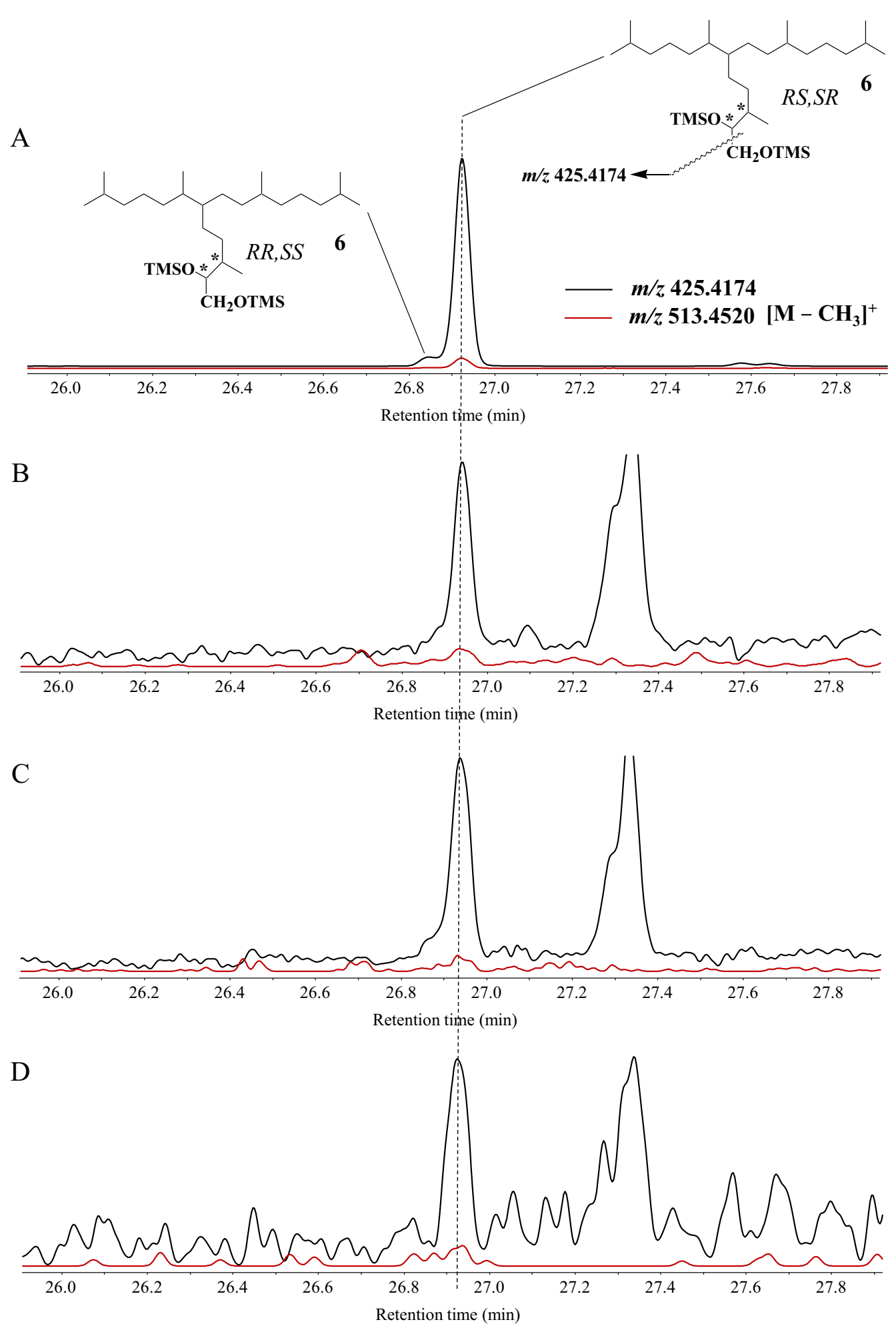

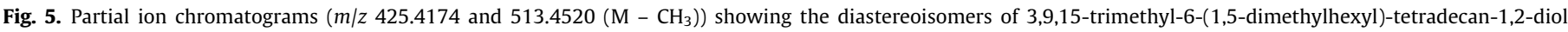

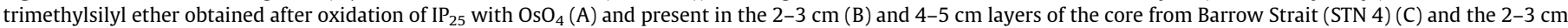
layer of the core from the western Amundsen Gulf (STN 408) (D).

This conclusion is further supported by the detection of an additional oxidation product in sediments (Fig. 4B), tentatively attributed to 2,6,10,14-tetramethyl-7-(3-methylpenten-4-yl)pentadecan-6-ol (8), which was absent in the incubation experiments (Fig. 4A).
Finally, although each of 1-5 could be readily identified during the incubation reactions, they were only ever present in low abundances and none accumulated over time. We attribute this to the likely secondary oxidation of primary hydroperoxides to polar and oligomeric compounds (Fig. 8), which are not detectable using 


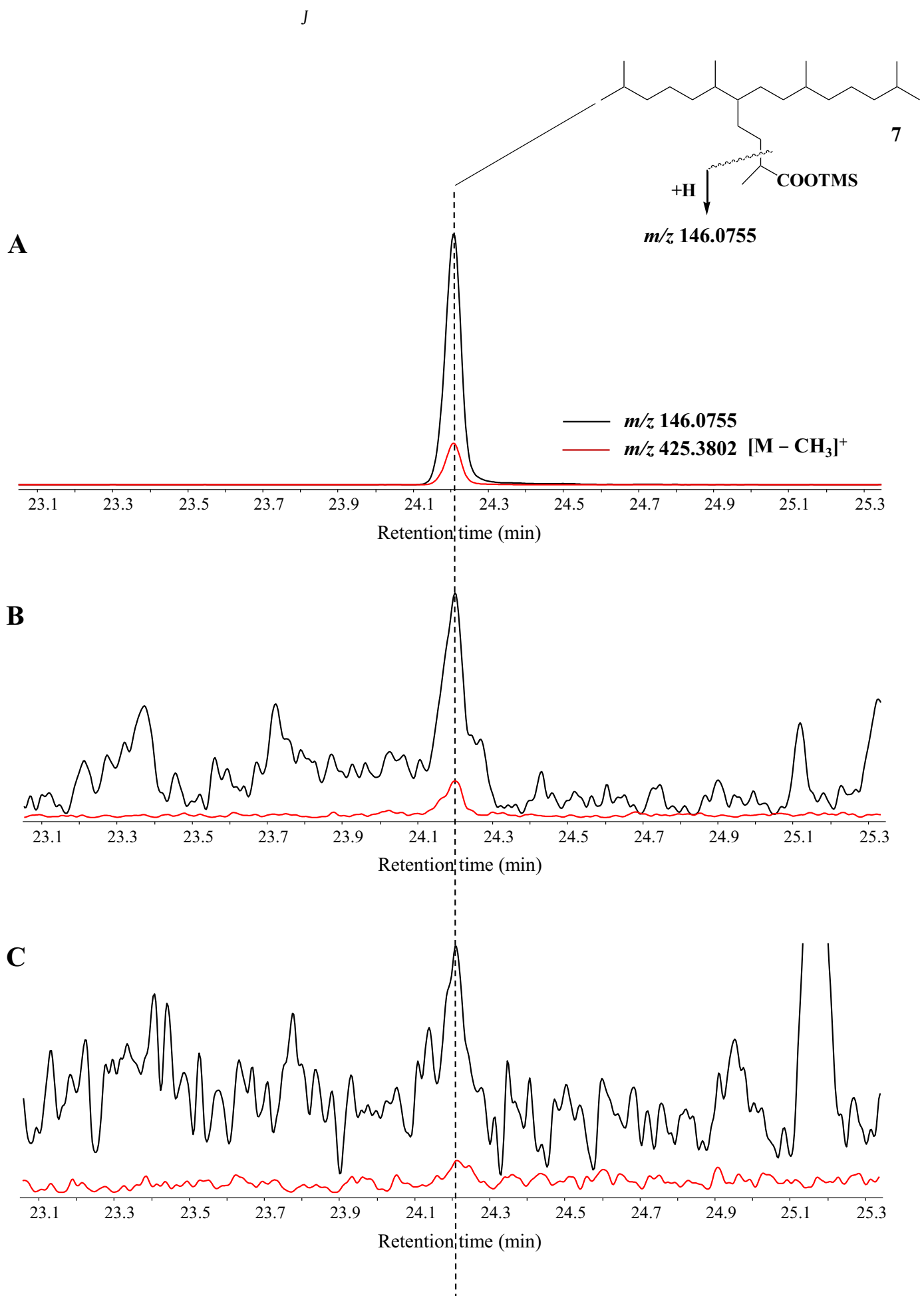

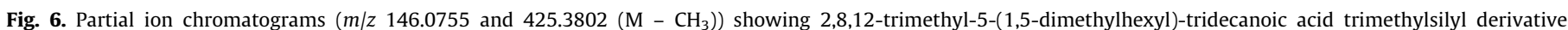

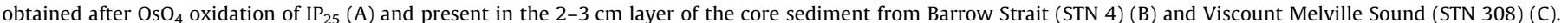

the GC-QTOFMS method employed here. This kind of secondary oxidation was described previously for other HBIs (Rontani et al., 2014).

\subsection{Degradation of epi-brassicasterol and 24-methylenecholesterol}

Due to the different positions of the double bonds in their alkyl chains (see Appendix A), an enhanced autoxidative and photooxidative reactivity of epi-brassicasterol compared to 24-methylenecholesterol would be expected. Indeed, the $\mathrm{C}-\mathrm{H}$ bond energy for allylic hydrogens is lower for internal double bonds than it is for terminal double bonds $(77 \mathrm{kcal} / \mathrm{mol} \mathrm{vs} 85 \mathrm{kcal} / \mathrm{mol})$ (Schaich, 2005), thus making allylic hydrogen abstraction more favourable in epi-brassicasterol. Moreover, on the basis of degradation rates of singlet oxygen $\left({ }^{1} \mathrm{O}_{2}\right)$ with terminal and internal double bonds $\left(4.0 \times 10^{3}\right.$ and $7.7 \times 10^{3} \mathrm{M}^{-1} \mathrm{~s}^{-1}$, respectively; Hurst et al., 1985), Type II photosensitized oxidation of epi-brassicasterol should also be favoured compared to 24-methylenecholesterol. However, in natural settings, it was previously reported that autoxidation (Rontani et al., 2014) and photooxidation 

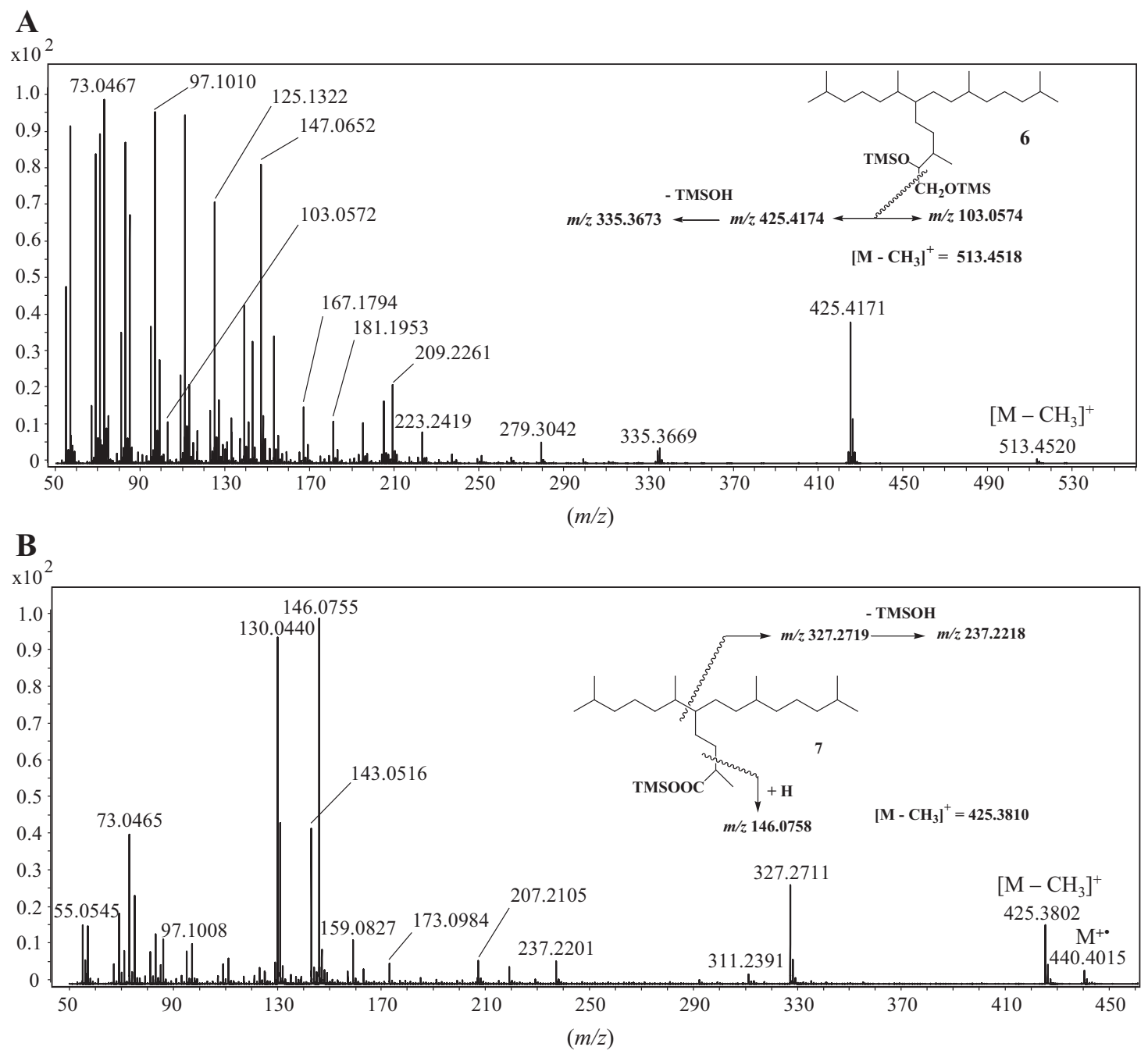

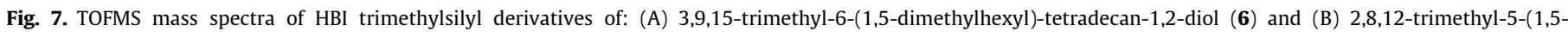
dimethylhexyl)-tridecanoic acid (7).

(Rontani et al., 2012, 2016) processes act more intensively on 24methylenecholesterol than on epi-brassicasterol, at least in mixed phytoplanktonic assemblages. These differences in reactivity can be attributed to the involvement of intra-cellular compartmentalization effects, which may significantly modify the reactivity of lipids towards autoxidative and photooxidative processes according to their location in phytoplanktonic cells (Rontani, 2012). This enhanced reactivity of 24-methylenecholesterol towards autoxidation in phytoplanktonic cells suggests that an increase in the $\mathrm{Bra} / 24-\mathrm{Me}$ ratio may be a good indicator of autoxidation processes in sediments, especially as the main autoxidative products of these two sterols are unspecific and labile $7 \alpha / \beta$-hydroperoxysteroids (Christodoulou et al., 2009; Rontani et al., 2009).

In contrast to autoxidation reactions, aerobic microbial degradation of $\Delta^{5}$-sterols involves two processes: side-chain elimination and ring opening (Rostoniec et al., 2009). The degradation is initiated by oxidation of the $3 \beta$-hydroxyl moiety and isomerization of the $\Delta^{5}$ double bond to the $\Delta^{4}$ position (Sojo et al., 1997). Further degradation of the resulting 4-steren-3-one proceeds via hydroxylation at $C_{26}$ to initiate side-chain degradation, or oxidation of rings A and $B$ resulting in the cleavage of the ring structure $(9,10$-secopathway; Philipp, 2011). In the case of cholesterol, the degradation of the 26-hydroxylated alkyl chain may be carried out after oxidation to the corresponding acid by classical sequences of $\beta$-oxidation (Rostoniec et al., 2009). In contrast, in the case of epi-brassicasterol and 24-methylenecholesterol, due to the presence of a methyl or methylene group at C-24, the involvement of alternating $\beta$-decarboxymethylation (Cantwell et al., 1978) and $\beta$-oxidation sequences is needed (Fig. 9). The very close degradation rates of these two sterols observed after incubation of phytoplanktonic cells in the presence of sediment inoculum under oxic conditions (Table 1) may be attributed to the involvement of a 2,3-enoyl-CoA isomerase (Ratledge, 1994). Indeed, these widely distributed enzymes may catalyze the isomerisation of the methylidene double bond to the C24-25 position in the case of 24-methylenecholesterol (Fig. 9), thus permitting the involvement of a similar degradation process of the alkyl side-chain in the case of the two sterols.

Under anoxic conditions, ring cleavage of $\Delta^{5}$-sterols may be mediated by oxygen-independent enzymatic processes (Chiang et al., 2007). In the case of cholesterol, only hydroxylation of the side chain at C-25 has been shown to occur, with the resulting tertiary alcohol not oxidized further (Chiang et al., 2007). For sterols with more substituted or unsaturated side chains, such as sitosterol, fucosterol and isofucosterol, similar degradation rates were observed following incubation of cells of the microalga Nannochloropsis salina in anoxic sediment slurries (Grossi et al., 2001). This suggests that changes to the sterol side chain have little 


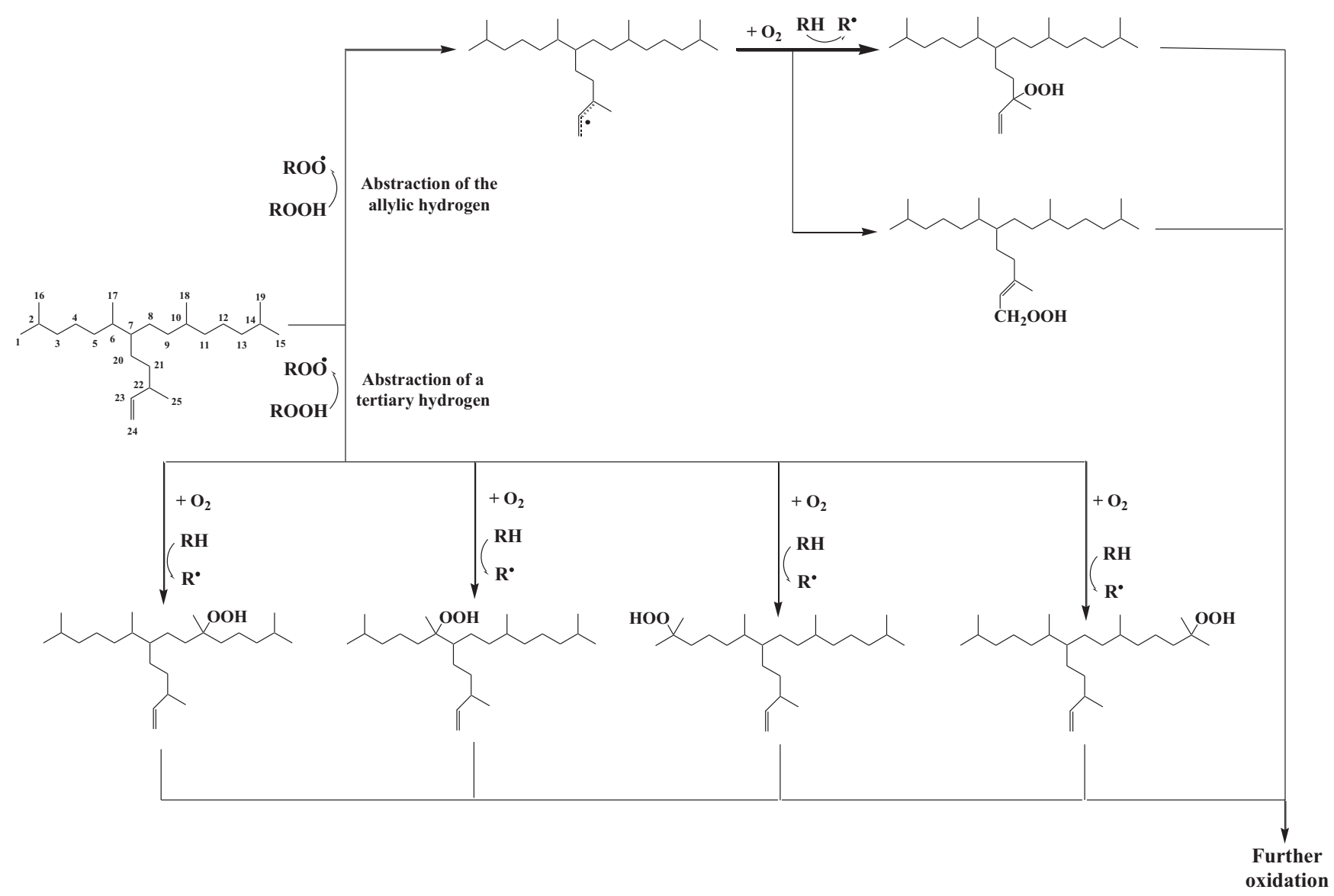

Fig. 8. Proposed mechanisms for the autoxidative degradation of $\mathrm{IP}_{25}$.

impact on the overall degradation rates under anoxic conditions. As such, in the absence of any reported experimental data, it is reasonable to propose similar anaerobic degradation rates for epibrassicasterol and 24-methylenecholesterol, especially given their common ring structure. Overall, therefore, aerobic and anaerobic bacterial degradation processes should not induce significant changes to the Bra/24-Me ratio in sediments.

\subsection{Degradation of $I P_{25}$, epi-brassicasterol and 24- methylenecholesterol in Arctic sediments}

Due to the extremely low rate of autoxidation of $\mathrm{IP}_{25}$ in solution, even at higher temperature (e.g., $65^{\circ} \mathrm{C}$ ), it was suggested previously that it should be largely unaffected by autoxidative degradation processes in the Arctic, at least in comparison with lipids of similar structure such as other HBIs with greater unsaturation (Rontani et al., 2014). However, here we show that autoxidative degradation of $\mathrm{IP}_{25}$ may occur under more 'forced' conditions and such processes may also take place in Arctic surface sediments. Indeed, due to recent evidence of strong lipoxygenase activity (a well-known source of radicals; Fuchs and Spiteller, 2014) in bacteria associated with ice algae (Amiraux et al., 2017) and in terrestrial particulate organic matter discharged from Arctic rivers (Galeron et al., 2018), autoxidative degradation reactions can even be dominant in Arctic sediments (Rontani et al., 2012, 2017), despite the low temperatures. The autoxidation of $\mathrm{IP}_{25}$ in sediments possessing a thick oxic layer, where the contact of ice algal detritus with oxygen may be relatively long, therefore represents a viable degradation pathway of this biomarker in near-surface sediments.
Consistent with this suggestion, the decrease in $\mathrm{IP}_{25}$ concentration observed in the oxic layer of sediments from Viscount Melville Sound (STN 308) (between 3 and $10 \mathrm{~cm}$ ) and the western Amundsen Gulf (STN 408) (between 0 and $3 \mathrm{~cm}$ ) (Fig. 3) may potentially be attributed to the involvement of oxic degradation processes such as aerobic biodegradation (Robson and Rowland, 1988) or autoxidation, and this last suggestion is supported further by the increase of the Bra/24-Me ratio within the same sediments (Fig. 3). In contrast, the strong decrease in Bra/24-Me observed in the bottom of the oxic layer of sediments from the western Amundsen Gulf (STN 408) is potentially due to an input of fresh algal material (with a low Bra/24-Me ratio) during this period. This suggestion is supported by the observation of a 10 -fold increase in phytoplanktonic sterol concentration in the $6-7 \mathrm{~cm}$ horizon compared to the $4-5 \mathrm{~cm}$ layer. Further, Brown (2011) proposed that rapid decreases in sedimentary $\mathrm{IP}_{25}$ concentration in some other cores from the Canadian Arctic could potentially reflect degradation processes, more generally. In contrast, the more consistent concentration of $\mathrm{IP}_{25}$ in anoxic sediments from Barrow Strait (STN 4) and the western Amundsen Gulf (STN 408) (Fig. 3) is likely indicative of enhanced resistance to oxidation under such conditions. Unfortunately, we were not able to detect the primary autoxidation products of $\mathrm{IP}_{25}$ in sediments other than from Barrow Strait (STN 4), likely due to: (i) their further oxidation (as suggested from the incubation reactions), especially in the oxic layers of cores from Viscount Melville Sound (STN 308) and the western Amundsen Gulf (STN 408) and (ii) the detection limits of GC-QTOFMS analyses. However, despite the general resistance of $\mathrm{IP}_{25}$ towards free radical oxidation, as reported previously (Rontani et al., 2011, 2014), the detection of compounds $\mathbf{1 , 3}, \mathbf{4}$ and $\mathbf{5}$ (Fig. 4) shows that 


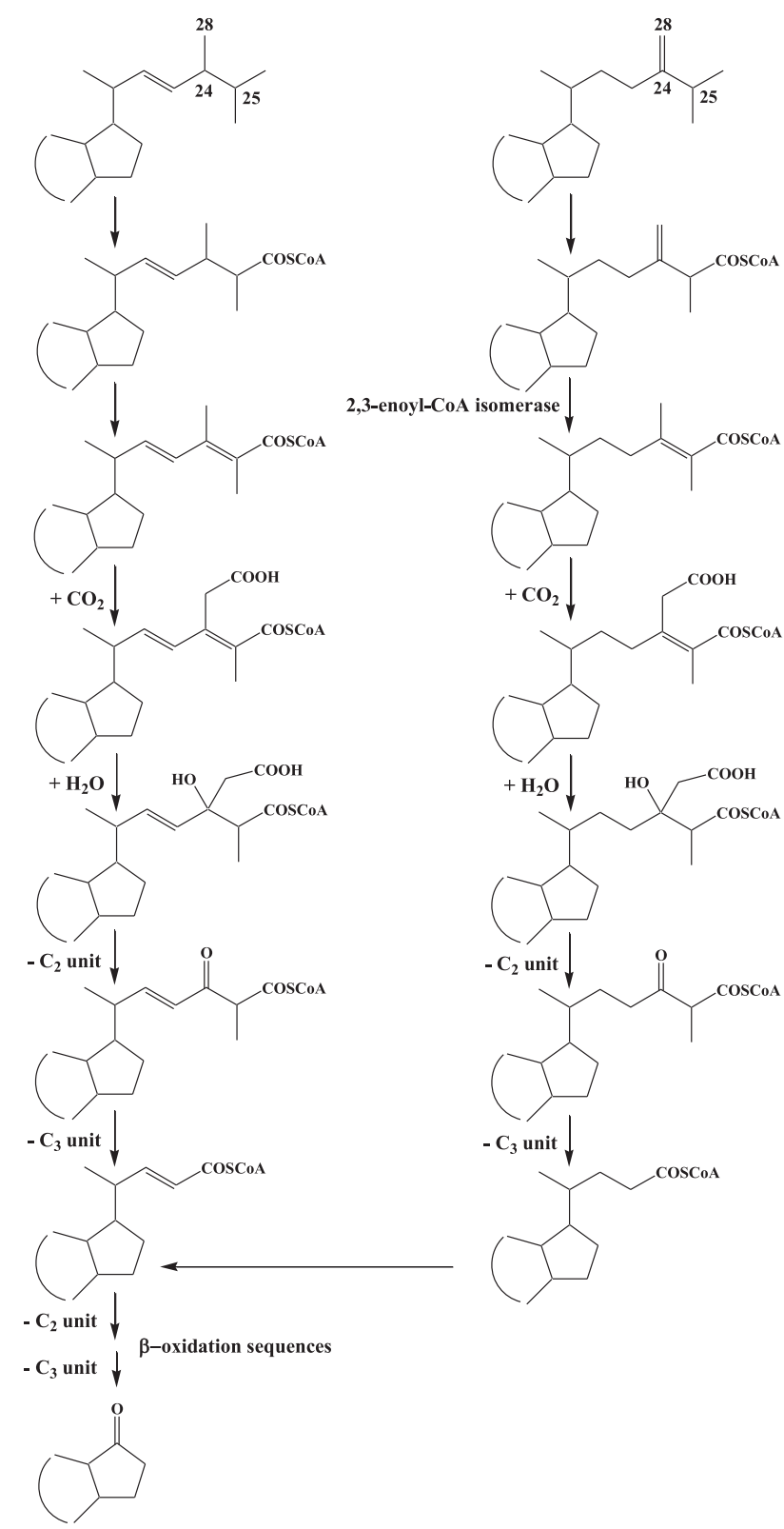

Fig. 9. Proposed mechanisms for the aerobic bacterial degradation of the alkyl sidechain of epi-brassicasterol and 24-methylenecholesterol.

this HBI alkene can be susceptible to autoxidation in Arctic sediments, an environment where such processes have previously been shown to be enhanced for some other lipids (Rontani et al., 2012, 2017). Further, this vulnerability towards autoxidation may be especially prevalent in cases where sequestered ice algal material experiences long residence times in the oxic layer.

Interestingly, compounds $\mathbf{6}$ and $\mathbf{7}$ could be detected in anoxic sediments from Barrow Strait (STN 4) and oxic sediments from Viscount Melville Sound (STN 308) and the western Amundsen Gulf (STN 408) (Figs. 5 and 6). We attribute the formation of such compounds to aerobic or anaerobic bacterial metabolism of $\mathrm{IP}_{25}$. In contrast, a mechanism involving autoxidative production (via epoxidation and subsequent hydrolysis; Schaich, 2005) is discarded on the basis of: (i) the detection of only one pair of enantiomers of compound $\mathbf{6}$ in sediments (Fig. 5) and (ii) the lack of compounds $\mathbf{6}$ and $\mathbf{7}$ observed during our in vitro autoxidation experiments. Aerobic bacterial degradation of $\mathrm{IP}_{25}$ may be initiated either via attack on the double bond or by the same mechanisms associated with $n$-alkane metabolism (i.e., attack of terminal methyl groups; Morgan and Watkinson, 1994). Oxidation across the double bond in $\mathrm{IP}_{25}$ can produce diol $\mathbf{6}$ via the corresponding epoxide 9 (Soltani et al., 2004) (Fig. 10). Previously, it was demonstrated that various pristenes and phytenes (also isoprenoid alkenes) can be rapidly biodegraded by sedimentary bacteria under anaerobic conditions, mainly by hydration reactions (Rontani et al., 2013). Enzymes that catalyze the addition of water to isolated and electron-rich carbon-carbon double bonds are termed hydratases and display a high degree of enantioselectivity (Resch and Hanefeld, 2015). In the case of $\mathrm{IP}_{25}$, addition of water to the C23-24 double bond results in the formation of 3,9,13-trimethyl6-(1,5-dimethylhexyl)-tetradecan-2-ol (10) (Fig. 10), which subsequently oxidises to the corresponding ketone (11). Mechanisms involving hydration of the enol forms of the keto group have been proposed for the anaerobic metabolism of isoprenoid ketones by denitrifiers (Rontani et al., 1999, 2013). Hydration of the enol form under kinetic control of the ketone $\mathbf{1 1}$ affords the diol $\mathbf{6}$ (Fig. 10). This diol may be subsequently cleaved to form 2,8,12-trimethyl5-(1,5-dimethylhexyl)-tridecanal (12), which may then be fully metabolized via 2,8,12-trimethyl-5-(1,5-dimethylhexyl)tridecanoic acid (7) by alternating $\beta$-oxidation and $\beta$-decarboxymethylation sequences (Cantwell et al., 1978; Rontani and Volkman, 2003). These interesting results suggest that $\mathrm{IP}_{25}$ may be also affected by bacterial degradation processes in Arctic sediments, although the extent to which this occurs remains to be determined.

\subsection{Implications for palaeo sea ice reconstruction}

The identification of some degradation pathways of $\mathrm{IP}_{25}$ in some Arctic marine sediments raises potentially important questions regarding the use of this biomarker as a reliable proxy measure of past sea ice. However, the failure to investigate the occurrence of any of the degradation products described herein in previous studies, prevents a comprehensive evaluation of the importance of $\mathrm{IP}_{25}$ degradation from being made at this stage. In the meantime, analysis of an extensive set of surface sediments from different Arctic regions has revealed excellent agreement between $\mathrm{IP}_{25}$ content and known sea ice cover (e.g., Müller et al., 2011; Stoynova et al., 2013; Navarro-Rodriguez et al., 2013; Xiao et al., 2013, 2015; Belt et al., 2015; Köseoğlu et al., 2018; Ribeiro et al., 2017), while $\mathrm{IP}_{25}$ data obtained from several short core records (typically covering recent decades to centuries) show generally good agreement with known sea ice conditions derived either from historical records or satellite data (Alonso-García et al., 2013; Weckström et al., 2013; Cormier et al., 2016), including examples where $\mathrm{IP}_{25}$ concentration increases with depth (e.g., Massé et al., 2008; Andrews et al., 2009; Vare et al., 2010; Cabedo-Sanz and Belt, 2016). However, in a recent study from the Chukchi-Alaskan margin, a decline in $\mathrm{IP}_{25}$ abundance in near-surface sediments was suggested to indicate a combined influence of diagenesis and long-range sediment transport (Polyak et al., 2016). Further, the previously reported surface sediment datasets (and their relationship to known sea ice cover) might need re-examination in light of the evidence described herein for at least partial $\mathrm{IP}_{25}$ degradation in some near-surface sediments.

Interestingly, although there is a clear decline in $\mathrm{IP}_{25}$ concentration with depth in the box core from Viscount Melville Sound (STN 308) (Fig. 3), a similarly continuous negative trend was not apparent in the cores from either Barrow Strait (STN 4) or the western Amundsen Gulf (STN 408) (Fig. 3), despite the detection of $\mathrm{IP}_{25}$ oxidation products in both cases (Fig. 5D). This suggests that climatic influences likely exceeded those from degradation, although the possible impact of bioturbation, a feature in some near-surface sediments, cannot be totally ruled out at this stage. However, 


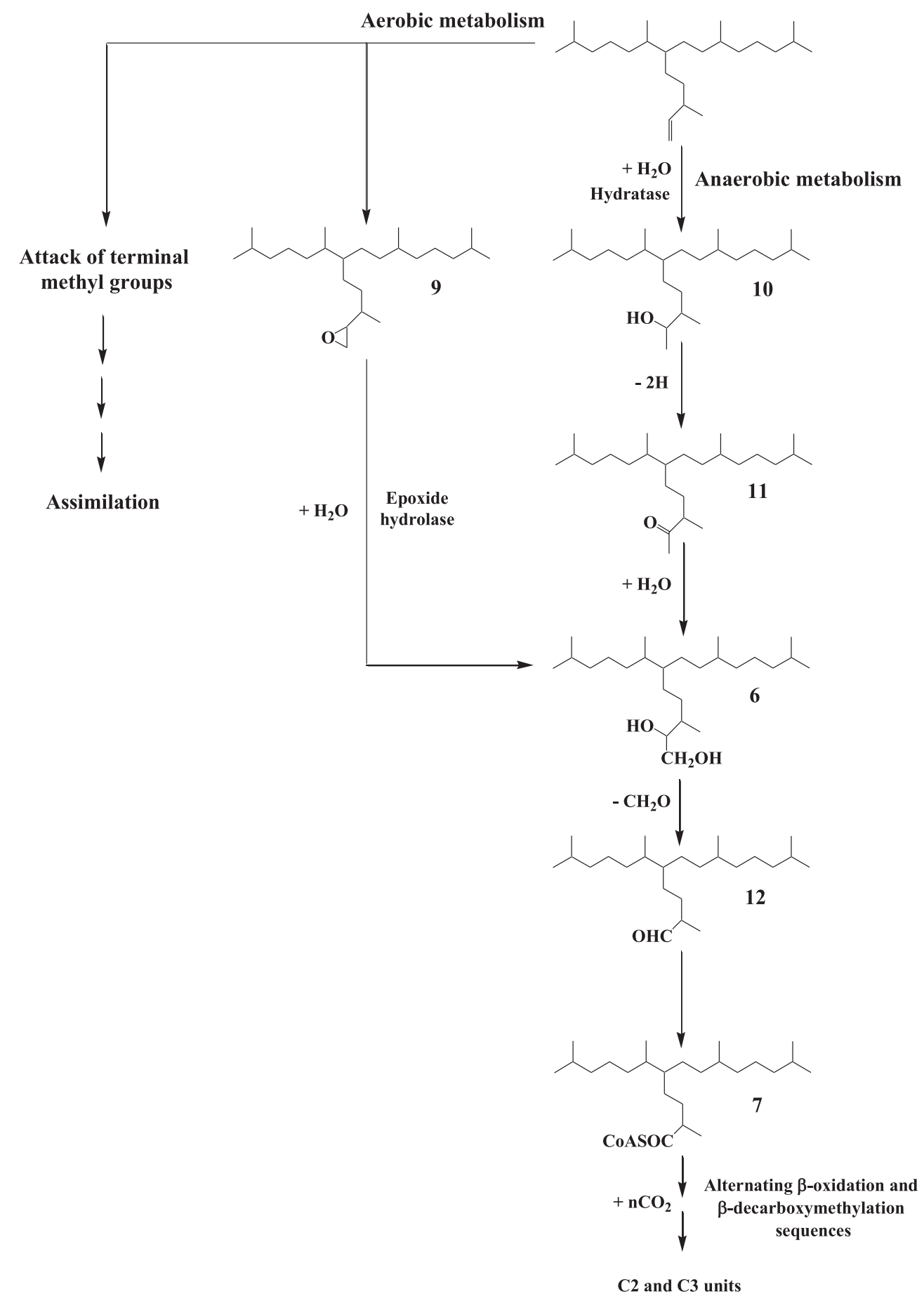

Fig. 10. Proposed mechanisms for the aerobic and anaerobic bacterial degradation of $\mathrm{IP}_{25}$.

preliminary ${ }^{210} \mathrm{~Pb}$ data suggest that bioturbation is negligible in cores from Barrow Strait (STN4) and Viscount Melville Sound (STN308), and confined to the (at most) upper $2 \mathrm{~cm}$ in the core from the western Amundsen Gulf (STN408) (S. Schmidt, personal communication).

For longer records (i.e. those beyond recent centuries), a common feature in many $\mathrm{IP}_{25}$-based sea ice reconstructions has been a reduction in $\mathrm{IP}_{25}$ concentration over time, especially during the Holocene (e.g., Vare et al., 2009; Belt et al., 2010; Fahl and Stein, 2012; Müller et al., 2012; Hörner et al., 2016; Kölling et al., 2017; Stein et al., 2017). Such changes have generally been interpreted as reflecting an increase in sea ice extent or duration from the warm early Holocene through neoglacial conditions towards present, an interpretation generally supported with other paleoclimatic proxy data. The often higher $\mathrm{IP}_{25}$ concentrations observed in older sections of the same (or related) records, covering the Younger Dryas stadial (ca. 12.9-11.5 kyr BP) (Cabedo-Sanz et al., 2013; Müller and Stein, 2014; Belt et al., 2015; Méheust et al., 2015; Jennings et al., 2017) and the Last Glacial Maximum (LGM; e.g., Müller and Stein, 2014; Hoff et al., 2016) provide further evidence of substantial climatic overprinting within biomarker profiles.

Resolving the relative contributions of climatic influence and diagenetic alteration on downcore $\mathrm{IP}_{25}$ (and other biomarker) distributions is likely to remain a challenge from an analytical perspective, however, not least because, on the basis of our new 
results described here, the oxidation products of $\mathrm{IP}_{25}$ are unlikely to accumulate in sufficient amounts to enable their quantification (or even detection), especially since $\mathrm{IP}_{25}$ content itself is often quite low in Arctic marine sediments. On the other hand, the measurement of certain biomarker ratios such as Bra/24-Me may prove useful for assessing such degradation processes, especially when used alongside $\mathrm{IP}_{25}$ concentration profiles; however, the potential for changes in environmental conditions to also influence such ratios should also be considered. Further, the measurement of redox boundary layers in upper sections of sediment cores might also provide additional insights into the nature of different degradation processes.

Finally, it is interesting to note that we were not able to detect any $\mathrm{IP}_{25}$ oxidation products in our sample of sea ice algae, which supports conclusions from previous studies that it is largely resistant to abiotic alteration in the host matrix (Rontani et al., 2014) and also in the water column soon after ice melt (Brown et al., 2016; Rontani et al., 2016).

\section{Conclusions}

This study represents the first attempt to evaluate, via oxidative product identification, the possible fate of $\mathrm{IP}_{25}$ in Arctic sediments. Laboratory-based autoxidation of the Arctic sea ice diatom biomarker $\mathrm{IP}_{25}$ results in the formation of a series of oxidation products that could be characterised using high resolution GC-MS methods. Some of the same oxidation products could also be identified in sediment material from the Canadian Arctic although their accumulation was very low, likely due to further oxidation. The detection of bacterial metabolites of $\mathrm{IP}_{25}$ showed that this $\mathrm{HBI}$ alkene may also be affected by aerobic and/or anaerobic degradation processes in sediments. We suggest that complementary evidence for autoxidation and biodegradation processes may potentially be obtained from measurement of certain phytoplankton sterol ratios, although these may also be influenced by changes to the overlying climatic conditions.

Although degradation of $\mathrm{IP}_{25}$ has, to date, not been considered in detail within $\mathrm{IP}_{25}$-based sea ice reconstructions, our initial overview of previous studies suggests that climatic contributions to sedimentary $\mathrm{IP}_{25}$ distributions likely exceed the impact of sedimentary degradation, at least in the albeit still limited number of case studies thus far reported. On the other hand, oxidative degradation may have a significant impact on $\mathrm{IP}_{25}$ concentration in some near-surface material, especially in cases where the oxic layer represents relatively long time intervals. In any case, we suggest that such degradation processes should be considered more carefully in future sea ice reconstructions based on $\mathrm{IP}_{25}$.

\section{Acknowledgments}

Financial support from the Centre National de la Recherche Scientifique (CNRS) and the Aix-Marseille University is gratefully acknowledged. Thanks are due to the FEDER OCEANOMED ( ${ }^{\circ}$ 1166-39417) for the funding of the apparatus employed. We are grateful to Lindsay Vare for providing us with the redox boundary information used in this study and for carrying out some of the sediment extractions for $\mathrm{IP}_{25}$ analysis. Patricia Cabedo-Sanz is acknowledged for conducting calibration experiments that enabled us to subsequently quantify $\mathrm{IP}_{25}$ from archived GC-MS data. We also thank Thomas Brown for fruitful discussions regarding the potential degradation of $\mathrm{IP}_{25}$ in Arctic sediments. We are grateful to Lindsay Vare, Guillaume Massé, André Rochon and the officers and crew of the CCGS Amundsen for help with obtaining box core sediment material. Finally, we thank the Associate Editor, Kirsten
Fahl and an anonymous reviewer for their useful and constructive comments.

\section{Appendix A}

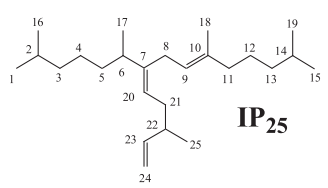<smiles>CCC(C)(C)CCC(CCC(C)CCCC(C)C)C(C)CCCC(C)C</smiles><smiles>CC(C)CCCC(C)C(CCC(C)CO)CCC(C)CO</smiles><smiles>C=CC(C)CCC(CCC(C)CCCC(C)(C)O)C(C)CCCC(C)C</smiles><smiles>CCCCC(CCC(C)CC)C(C)CCCC(C)CCCC(C)C</smiles><smiles>CC(C)CCCC(C)C(CCCC(C)C)CCC(C)C</smiles><smiles>CC(C)CCCC(C)CCC(CCC(O)CO)C(C)CCCC(C)C</smiles><smiles>CC(C)CCCC(C)C(CCCC(C)C)CCC(C)C</smiles><smiles>CC(C)CCCC(C)(O)C(CCC(C)C)CCC(C)C</smiles><smiles>CC(C)CCCC(C)CCC(CCC(C)C)C(C)CCCC(C)C</smiles><smiles>CC(C)CCCC(C)CCC(CCC(C)C)C(C)CCCC(C)C</smiles><smiles>CC(C)CCCC(C)C(CCC(C)C)CCC(C)C(C)O</smiles><smiles>CC(C)CCCC(C)C(CCCC(C)C)CCC(C)C=O</smiles><smiles>C=C(CCC(C)C1CCC2C3CC=C4CC(O)CCC4(C)C3CCC12C)C(C)C</smiles><smiles>CC(C)C(C)/C=C/C(C)C1CCC2C3CC=C4CC(O)CCC4(C)C3CCC12C</smiles>

Epi-brassicasterol

24-Methylenecholesterol

\section{Appendix B. Supplementary material}

Supplementary data associated with this article can be found, in the online version, at https://doi.org/10.1016/j.orggeochem.2018. 01.003 . 


\section{References}

Alonso-García, M., Andrews, J.T., Belt, S.T., Cabedo-Sanz, P., Darby, D., Jaeger, J. 2013. A comparison between multi-proxy and historical data (AD 1990-1840) of drift-ice conditions on the East Greenland shelf $\left(\sim 66^{\circ} \mathrm{N}\right)$. The Holocene 23 , 1672-1683.

Amiraux, R., Belt, S.T., Vaultier, F., Galindo, V., Gosselin, M., Bonin, P., Rontani, J.-F. 2017. Monitoring of photooxidative and osmotic bacterial stresses in Arctic using specific lipid tracers. Marine Chemistry 194, 89-99.

Andrews, J.T., Belt, S.T., Olafsdottir, S., Massé, G., Vare, L.L., 2009. Sea ice and climate variability for NW Iceland/Denmark Strait over the last 2000 cal. yr BP. The Holocene 19, 775-784.

Belt, S.T., Müller, J., 2013. The Arctic sea ice biomarker $\mathrm{IP}_{25}$ : a review of current understanding, recommendations for future research and applications in palaeo sea ice reconstructions. Quaternary Science Reviews 79, 9-25.

Belt, S.T., Massé, G., Rowland, S.J., Poulin, M., Michel, C., LeBlanc, B., 2007. A novel chemical fossil of palaeo sea ice: $\mathrm{IP}_{25}$. Organic Geochemistry 38, 16-27.

Belt, S.T., Vare, L.L., Massé, G., Manners, H.R., Price, J.C., MacLachlan, S.E., Andrews, J. T., Schmidt, S., 2010. Striking similarities in temporal changes to seasonal sea ice conditions across the central Canadian Arctic Archipelago over the last 7,000 years. Quaternary Science Reviews 29, 3489-3504.

Belt, S.T., Brown, T.A., Navarro-Rodriguez, A., Cabedo-Sanz, P., Tonkin, A., Ingle, R. 2012. A reproducible method for the extraction, identification and quantification of the Arctic sea ice proxy $\mathrm{IP}_{25}$ from marine sediments. Analytical Methods 4, 705-713.

Belt, S.T., Brown, T.A., Ringrose, A.E., Cabedo-Sanz, P., Mundy, C.J., Gosselin, M., Poulin, M., 2013. Quantitative measurements of the sea ice diatom biomarker $\mathrm{IP}_{25}$ and sterols in Arctic sea ice and underlying sediments: further considerations for palaeo sea ice reconstruction. Organic Geochemistry 62 33-45.

Belt, S.T., Cabedo-Sanz, P., Smik, L., Navarro-Rodriguez, A., Berben, S.M.P., Knies, J Husum, K., 2015. Identification of paleo Arctic winter sea ice limits and the marginal ice zone: optimised biomarker-based reconstructions of late Quaternary Arctic sea ice. Earth and Planetary Science Letters 431, 127-139.

Berben, S.M.P., Husum, K., Cabedo-Sanz, P., Belt, S.T., 2014. Holocene sub-centennia evolution of Atlantic Water inflow and sea ice distribution in the western Barents Sea. Climate of the Past 10, 181-198.

Berben, S.M.P. Husum, K. Navarro-Rodriguez, A., Belt, S.T., Aagaard-Sørensen, S. 2017. Semi-quantitative reconstruction of early to late Holocene spring and summer sea ice conditions in the northern Barents Sea. Journal of Quaternary Science 32, 587-603.

Brown, T.A. 2011. Production and Preservation of the Arctic Sea Ice Diatom Biomarker IP25 Ph.D. thesis. University of Plymouth, UK.

Brown, T.A., Belt, S.T., Tatarek, A., Mundy, C.J., 2014. Source identification of the Arctic sea ice proxy $\mathrm{IP}_{25}$. Nature Communications 5, 4197.

Brown, T.A., Belt, S.T., Gosselin, M., Levasseur, M., Poulin, M., Mundy, C.J., 2016. Quantitative estimates of sinking sea ice particulate organic carbon based on the biomarker $\mathrm{IP}_{25}$. Marine Ecology Progress Series 546, 17-29.

Cabedo-Sanz, P., Belt, S.T., 2016. Seasonal sea ice variability in eastern Fram Strait over the last 2,000 years. Arktos 2, 22.

Cabedo-Sanz, P., Belt, S.T., Knies, J.K., Husum, K., 2013. Identification of contrasting seasonal sea ice conditions during the Younger Dryas. Quaternary Science Reviews 79, 74-86.

Cabedo-Sanz, P., Smik, L., Belt, S.T., 2016. On the stability of various highly branched isoprenoids (HBI) lipids in stored sediments and sediment extracts. Organic Geochemistry 97, 74-77.

Cantwell, S.G., Lau, E.P., Watt, D.S., Fall, R.R., 1978. Biodegradation of acyclic isoprenoids by Pseudomonas species. Journal of Bacteriology 135, 324-333.

Chiang, Y.-R., Ismael, W. Müller, M., Fuchs, G., 2007. Initial steps in the anoxic metabolism of cholesterol by the denitrifying Sterolibacterium denitrificans. The Journal of Biological Chemistry 282, 13240-13249.

Christodoulou, S., Marty, J.-C., Miquel, J.-C., Volkman, J.K., Rontani, J.-F., 2009. Use of lipids and their degradation products as biomarkers for carbon cycling in the northwestern Mediterranean Sea. Marine Chemistry 113, 25-40.

Cormier, M.-A., Rochon, A., de Vernal, A., Gélinas, Y., 2016. Multi-proxy study of primary production and paleoceanographical conditions in northern Baffin Bay during the last centuries. Marine Micropaleontology 127, 1-10.

Darby, D.A., Polyak, L., Bauch, H.A., 2006. Past glacial and interglacial conditions in the Arctic Ocean and marginal seas - a review. Progress in Oceanography 71 129-144.

Detlef, H., Belt, S.T., Sosdian, S.M., Smik, L., Lear, C.H., Hall, I.R., Cabedo-Sanz, P., Husum, K., Kender, S., 2018. Changes in sea ice dynamics in the eastern Bering Sea during the Mid-Pleistocene climate transition. Nature Communications. https://doi.org/10.1038/s41467-018-02845-5.

Fahl, K., Stein, R., 2012. Modern seasonal variability and deglacial/Holocene change of central Arctic Ocean sea-ice cover: new insights from biomarker proxy records. Earth and Planetary Science Letters 351-352, 123-133.

Fenchel, T., King, G.M., Blackburn, T.H., 1998. Bacterial Biogeochemistry: the Ecophysiology of Mineral Cycling. Academic Press, NY.

Fuchs, C., Spiteller, G., 2014. Iron release from the active site of lipoxygenase. Zeitschrift für Naturforschung C 55, 643-648.

Galeron, M.-A., Radakovitch, O., Charriere, B., Vaultier, F., Volkman, J.K., Bianchi, T.S. Ward, N.T., Medeiros, P., Sawakuchi, H., Tank, S., Kerhervé, P., Rontani, J.-F. 2018. Lipoxygenase-induced autoxidative degradation of terrestrial particulate organic matter in estuaries: a widespread process enhanced at high and low latitudes. Organic Geochemistry 115, 78-92.

Grossi, V., Blokker, P., Sinninghe Damsté, J.S., 2001. Anaerobic biodegradation of lipids of the marine microalga Nannochloropsis salina. Organic Geochemistry 32, 795-808.

Hartnett, H.E., Keil, R.G., Hedges, J.I., Devol, A.H., 1998. Influence of oxygen exposure time on organic carbon preservation in continental margin sediments. Nature $391,572-574$

Henrich, R., 1991. Cycles, rhythms, and events on high input and low input glaciated continental margins. In: Einsele, G., Ricken, W., Seilacher, A. (Eds.), Cycles and Events in Stratigraphy. Springer, Berlin Heidelberg, pp. 751-772.

Hoff, U., Rasmussen, T.L., Stein, R., Ezat, M.M., Fahl, K., 2016. Sea ice and millennialscale climate variability in the Nordic Seas $90 \mathrm{kyr}$ ago to present. Nature Communications 7, 12247.

Hörner, T., Stein, R., Fahl, K., Birgel, D., 2016. Post-glacial variability of sea ice cover, river run-off and biological production in the western Laptev Sea (Arctic Ocean) - a high resolution biomarker study. Quaternary Science Reviews 143, 133-149.

Hörner, T., Stein, R., Fahl, K., 2017. Evidence for Holocene centennial variability in sea ice cover based on $\mathrm{IP}_{25}$ biomarker reconstruction in the southern Kara Sea (Arctic Ocean). Geo-Marine Letters. https://doi.org/10.1007/s00367-0001700501-y.

Hurst, J.R., Wilson, S.L., Schuster, G.B., 1985. The ene reaction of singlet oxygen: kinetic and product evidence in support of a perepoxide intermediate. Tetrahedron 41, 2191-2197.

Jennings, A.E., Andrews, J.T., Ó Cofaigh, C., St. Onge, G., Sheldon, C., Belt, S.T., CabedoSanz, P., Hillaire-Marcel, C., 2017. Ocean forcing of Ice Sheet retreat in central west Greenland from LGM to the early Holocene. Earth and Planetary Science Letters 472, 1-13.

Knies, J., Cabedo-Sanz, P., Belt, S.T., Baranwal, S., Fietz, S., Rosell-Melé, A., 2014. The emergence of modern sea ice cover in the Arctic Ocean. Nature Communications 5, 5608 .

Kölling, H.M., Stein, R., Fahl, K., Perner, P., Moros, M., 2017. Short-term variability in late Holocene sea ice cover on the East Greenland Shelf and its driving mechanisms. Palaeogeography Palaeoclimatology Palaeoecology. https://doi. org/10.1016/j.palaeo.2017.06.024.

Köseoğlu, D., Belt, S.T., Smik, L., Yao, H., Panieri, G., Knies, J., 2018. Complementary biomarker-based methods for characterising Arctic sea ice conditions: a case study comparison between multivariate analysis and the $\mathrm{PIP}_{25}$ index. Geochimica et Cosmochimica Acta 222, 406-420.

Kristensen, E., 2000. Organic matter diagenesis at the oxic/anoxic interface in coastal marine sediments, with emphasis on the role of burrowing. Hydrobiologia 426, 1-24.

McCloskey, J.A., McClelland, M.J., 1965. Mass spectra of O-isopropylidene derivatives of unsaturated fatty esters. Journal of the American Chemical Society 87, 5090-5093.

Maiti, K., Carroll, J., Benitez-Nelson, C.R., 2010. Sedimentation and particle dynamics in the seasonal ice zone of the Barents Sea. Journal of Marine Systems 79, 185198.

Massé, G., Rowland, S.J., Sicre, M.-A., Jacob, J., Jansen, E., Belt, S.T., 2008. Abrupt climate changes for Iceland during the last millennium: evidence from high resolution sea ice reconstructions. Earth and Planetary Science Letters 269, 565-569.

Méheust, M., Stein, R., Fahl, K., Max, L., Riethdorf, J.R., 2015. High-resolution $\mathrm{IP}_{25^{-}}$ based reconstruction of sea-ice variability in the western North Pacific and Bering Sea during the past 18,000 years. Geo-Marine Letters 36, 101-111.

Morgan, P., Watkinson, R.J., 1994. Biodegradation of components of petroleum. In: Ratledge, C. (Ed.), Biochemistry of Microbial Degradation. Kluwer Academic Publishers, Dordrecht, pp. 1-25.

Mudie, P.J., Rochon, A., Prins, M.A., Soenarjo, D., Troelstra, S.R., Levac, E., Scott, D.B., Roncaglia, L., Kuijpers, A., 2006. Late Pleistocene-Holocene marine geology of Nares Strait region: palaeoceanography from foraminifera and dinoflagellate cysts, sedimentology and stable isotopes. Polarforschung 74, 169-183.

Müller, J., Stein, R., 2014. High-resolution record of late glacial sea ice changes in Fram Strait corroborates ice-ocean interactions during abrupt climate shifts. Earth and Planetary Science Letters 403, 446-455.

Müller, J., Massé, G., Stein, R., Belt, S.T., 2009. Variability of sea-ice conditions in the Fram Strait over the past 30,000 years. Nature Geoscience 2, 772-776.

Müller, J., Wagner, A., Fahl, K., Stein, R., Prange, M., Lohmann, G., 2011. Towards quantitative sea ice reconstructions in the northern North Atlantic: a combined biomarker and numerical modelling approach. Earth and Planetary Science Letters 306, 137-148.

Müller, J., Werner, K., Stein, R., Fahl, K., Moros, M., Jansen, E., 2012. Holocene cooling culminates in sea ice oscillations in Fram Strait. Quaternary Science Reviews 47, $1-14$.

Navarro-Rodriguez, A., Belt, S.T., Brown, T.A., Knies, J., 2013. Mapping recent sea ice conditions in the Barents Sea using the proxy biomarker $\mathrm{IP}_{25}$ : implications for palaeo sea ice reconstructions. Quaternary Science Reviews 79, 26-39.

Philipp, B., 2011. Bacterial degradation of bile acids. Applied Microbiology and Biotechnology 89, 903-915.

Polyak, L., Belt, S.T., Cabedo-Sanz, P., Yamamoto, M., Park, Y.-H., 2016. Holocene seaice conditions and circulation at the Chukchi-Alaskan margin, Arctic Ocean, inferred from biomarker proxies. The Holocene 26, 1810-1821.

Ratledge, C., 1994. Biodegradation of oils, fats and fatty acids. In: Ratledge, C. (Ed.), Biochemistry of Microbial Degradation. Kluwer Academic Publishers, Dordrecht, pp. 89-142. 
Resch, V., Hanefeld, U., 2015. The selective addition of water. Catalysis Science and Technology 5, 1385-1399.

Ribeiro, S., Sejr, M.K., Limoges, A., Heikkilä, M., Andersen, T.J., Tallberg, P., Weckström, K., Husum, K., Forwick, M., Dalsgaard, T., Massé, G., Seidenkrantz, M.-S., Rysgaard, S., 2017. Sea ice and primary production proxies in surface sediments from a High Arctic Greenland fjord: spatial distribution and implications for palaeoenvironmental studies. Ambio 46 (Suppl. 1), S106-S118.

Robson, J.N., 1987. Synthetic and Biodegradation Studies of Some Sedimentary Isoprenoid Hydrocarbons PhD thesis. Plymouth Polytechnic, Plymouth.

Robson, J.N., Rowland, S.J., 1988. Biodegradation of highly branched isoprenoid hydrocarbons: a possible explanation of sedimentary abundance. Organic Geochemistry 13, 691-695.

Rontani, J.-F., 2012. Photo-and free radical-mediated oxidation of lipid components during the senescence of phototrophic organisms. In: Nagata, T. (Ed.), Senescence. Intech, Rijeka, pp. 3-31.

Rontani, J.-F., Volkman, J.K., 2003. Phytol degradation products as biogeochemical tracers in aquatic environments. Organic Geochemistry 34, 1-35.

Rontani, J.-F., Bonin, P., Volkman, J.K., 1999. Biodegradation of free phytol by bacterial communities isolated from marine sediments under aerobic and denitrifying conditions. Applied and Environmental Microbiology 65, 54845492.

Rontani, J.-F., Zabeti, N., Wakeham, S.G., 2009. The fate of marine lipids: biotic vs. abiotic degradation of particulate sterols and alkenones in the Northwestern Mediterranean Sea. Marine Chemistry 113, 9-18.

Rontani, J.-F., Belt, S.T., Vaultier, F., Brown, T.A., 2011. Visible light induced photooxidation of highly branched isoprenoid (HBI) alkenes: significant dependence on the number and nature of double bonds. Organic Geochemistry 42, 812 822 .

Rontani, J.-F., Charrière, B., Forest, A., Heussner, S., Vaultier, F., Petit, M., Delsaut, N., Fortier, L., Sempéré, R., 2012. Intense photooxidative degradation of planktonic and bacterial lipids in sinking particles collected with sediment traps across the Canadian Beaufort Shelf (Arctic Ocean). Biogeosciences 9, 4787-4802.

Rontani, J.-F., Bonin, P., Vaultier, F., Guasco, S., Volkman, J.K., 2013. Anaerobic bacterial degradation of pristenes and phytenes in marine sediments does not lead to pristane and phytane. Organic Geochemistry 58, 43-55.

Rontani, J.-F., Belt, S.T., Vaultier, F., Brown, T.A., Massé, G., 2014. Autoxidation and photooxidation of highly branched isoprenoid (HBI) alkenes: a combined kinetic and mechanistic study. Lipids 49, 481-494.

Rontani, J.-F., Belt, S.T., Brown, T.A., Amiraux, R., Gosselin, M., Vaultier, F., Mundy, C. J., 2016. Monitoring abiotic degradation in sinking versus suspended Arctic sea ice algae during a spring ice melt waters using specific lipid oxidation tracers. Organic Geochemistry 98, 82-97.

Rontani, J.-F., Galeron, M.-A., Amiraux, R., Artigue, L., Belt, S.T., 2017. Identification of di- and triterpenoid lipid tracers confirms the significant role of autoxidation in the degradation of terrestrial vascular plant material in the Canadian Arctic. Organic Geochemistry 108, 43-50.

Rostoniec, K.Z., Wilbrink, M.H., Capyk, J.K., Mohn, W.W., Ostendorf, M., van der Geize, R., Dijkhuisen, L., Eltis, L.D., 2009. Cytochrome P450 125 (CYP125) catalyses C26-hydroxylation to initiate sterol side-chain degradation in Rhodococcus jostii RHA. Molecular Microbiology 74, 1031-1043.
Schaich, K.M., 2005. Lipid oxidation: theoretical aspects. In: Shahidi, F. (Ed.), Bailey's Industrial Oil and Fat Products. John Wiley \& Sons, Chichester, pp. 269-355.

Seki, H., Ohyama, K., Sawai, S., Mizutani, M., Ohnishi, T., Sudo, H., Akashi, T., Aoki, T. Saito, K., Muranaka, T., 2008. Licorice $\beta$-amyrin 11-oxidase, a cytochrome P450 with a key role in the biosynthesis of the triterpene sweetener glycyrrhizin. Proceedings of the National Academy of Science of the United States of America 105, 14204-14209.

Sojo, M., Bru, R., Lopez-Molina, D., Garcia-Carmona, F., Arguelles, J.C., 1997. Celllinked and extracellular cholesterol oxidase activities from Rhodococcus erythropolis. Isolation and physiological characterization. Applied and Environmental Biotechnology 47, 583-589.

Soltani, M., Metzger, P., Largeau, C., 2004. Effects of hydrocarbon structure on fatty acid, fatty alcohols and $\beta$-hydroxy acid composition in the hydrocarbondegrading bacterium Marinobacter hydrocarbonoclasticus. Lipids 39, 491-505.

Stein, R., Fahl, K., 2000. Holocene accumulation of organic carbon at the Laptev Sea continental margin (Arctic Ocean): sources, pathways, and sinks. Geo-Marine Letters 20, 27-36.

Stein, R., Fahl, K., 2013. Biomarker proxy $\mathrm{IP}_{25}$ shows potential for studying entire Quaternary Arctic sea-ice history. Organic Geochemistry 55, 98-102.

Stein, R., Nam, S.I., Schubert, C., Vogt, C., Fütterer, D., Heinemeier, J., 1994a. The last deglaciation event in the eastern Central Arctic Ocean. Science 264, 692-696.

Stein, R., Schubert, C., Vogt, C., Fütterer, D., 1994b. Stable isotope stratigraphy, sedimentation rates, and salinity changes in the Latest Pleistocene to Holocene eastern central Arctic Ocean. Marine Geology 119, 333-355.

Stein, R., Fahl, K., Schreck, M., Knorr, G., Niessen, F., Forwick, M., Gebhardt, C., Jensen, L., Kaminski, M., Kopf, A., Matthiessen, J., Jokat, W., Lohmann, G., 2016. Evidence for ice-free summers in the late Miocene central Arctic Ocean. Nature Communications 7. https://doi.org/10.1038/ncomms11148. Article no. 11148.

Stein, R., Fahl, K., Schade, I., Manerung, A., Wassmuth, S., Niessen, F., Nam, S., 2017. Holocene variability in sea ice cover, primary production, and Pacific-Water inflow and climate change in the Chukchi and East Siberian Seas (Arctic Ocean). Journal of Quaternary Science 32, 362-379.

Stoynova, V., Shanahan, T.M., Hughen, K.A., de Vernal, A., 2013. Insights into circumArctic sea ice variability from molecular geochemistry. Quaternary Science Reviews 79, 63-73.

Vare, L.L., Massé, G., Belt, S.T., 2010. A biomarker-based reconstruction of sea ice conditions for the Barents Sea in recent centuries. The Holocene 40, 637-643.

Vare, L.L., Massé, G., Gregory, T.R., Smart, C.W., Belt, S.T., 2009. Sea ice variations in the central Canadian Arctic Archipelago during the Holocene. Quaternary Science Reviews 28, 1354-1366.

Weckström, K., Massé, G., Collins, L.G., Hanhijärvi, S., Bouloubassi, I., Sicre, M.-A. Seidenkrantz, M.-S., Schmidt, S., Andersen, T.J., Andersen, M.L., Hill, B., Kuijpers, A., 2013. Evaluation of the sea ice proxy $\mathrm{IP}_{25}$ against observational and diatom proxy data in the SW Labrador Sea. Quaternary Science Reviews 79, 53-62.

Xiao, X., Stein, R., Fahl, K., 2013. Biomarker distributions in surface sediments from the Kara and Laptev Seas (Arctic Ocean): indicators for organic-carbon sources and sea ice coverage. Quaternary Science Reviews 79, 40-52.

Xiao, X., Fahl, K., Müller, J., Stein, R., 2015. Sea-ice distribution in the modern Arctic Ocean: biomarker records from trans-Arctic Ocean surface sediments. Geochimica et Cosmochimica Acta 155, 16-29. 